\title{
Distribution of discontinuous mudstone beds within wave-dominated shallow-marine deposits: Star Point Sandstone and Blackhawk Formation, Eastern Utah, USA
}

\author{
Christian Haug Eide ${ }^{1,2}$, J. A. Howell ${ }^{1,3}$, S. J. Buckley ${ }^{1}$ \\ ${ }^{1}$ Uni CIPR, P.O. Box 8710, 5020 Bergen, Norway \\ ${ }^{2}$ Department of Earth Science, University of Bergen, P.O. Box 7803, 5020 Bergen, Norway \\ ${ }^{3}$ Now: School of Geosciences, University of Aberdeen, Rm 106, Meston Building, Rm 106, Meston Building, \\ Aberdeen, AB24 3UE, Scotland \\ Postprint, accepted for publication in AAPG Bulletin, January 20, 2014. \\ Version-on-record: http://dx.doi.org/10.1306/01201413106
}

\begin{abstract}
Deposits of wave-dominated shorelines are typically considered to act as relatively simple hydrocarbon reservoirs and are commonly modeled as "tanks of sand". However, important heterogeneities that can act as barriers to fluid flow occur at the parasequence, bedset and bed scales, especially in viscous oil or low permeability oil fields. Heterogeneities at the parasequence and bedset scale have been well-studied, but discontinuous mudstone-beds occurring within the shoreface have received little attention.

The Book Cliffs and Wasatch Plateau are among the best exposed and most well-studied deposits of wave-dominated shallow-marine systems in the world. Two parasequences within these outcrops have been studied in detail to investigate the distributions of intrashoreface shales and to propose models for the controls on their distribution. A dataset consisting of $30 \mathrm{~km}$ of virtual outcrops derived from oblique helicopter-mounted lidar scanning with supporting stratigraphic sections makes it possible to collect a large quantity of accurate geometric data of depositional elements from inaccessible cliffs.

A total of 921 discontinuous mudstone beds were measured. These occur as ellipses with long axes oriented normal to the paleoshoreline. Lengths and widths of these mudstone beds exhibit a lognormal distribution, with means of 21.9 and $13.8 \mathrm{~m}$ respectively. Within the shoreface succession, the number of mudstone beds increases downwards while size does not vary significantly with stratigraphic height. There is an average of $100 \mathrm{~m}$ cumulative length of shale per $100 \mathrm{~m}$ of horizontal outcrop; this increases threefold near both wave-dominated deltas and bedset boundaries that reflect minor sea-level fluctuations during progradation.
\end{abstract}

\section{Introduction}

Sediments deposited in wave-dominated shoreline systems (shorefaces and wave-dominated deltas) provide numerous, prolific hydrocarbon reservoirs, such as the Brent and Humber group deposits of the North Sea (e.g. Richards and Brown, 1986; Howell et al., 1996; 
Kadolsky et al., 1999; Husmo et al., 2003), the Wilcox Formation onshore Gulf of Mexico (e.g. Galloway et al., 2000), and numerous Tertiary delta systems of South East Asia (e.g. Hodgetts et al., 2001; Ainsworth et al., 2005). These reservoirs typically have simpler depositional architectures and are therefore easier to produce than reservoirs within fluvialand tide-dominated shoreline systems (Ainsworth et al 2005; Martinius et al., 2005; Howell et al., 2008a; Howell et al., 2008b;). Wave-dominated shallow marine systems are commonly treated as "tanks of sand", in which the shoreface is modeled as a shore-parallel belt of homogeneous sandstone (MacDonald and Aasen 1994; Howell et al., 2008a). While such an approach may be justified, recent studies (e.g. Ainsworth, 2010) illustrate that shoreface and wave-dominated deltaic systems commonly contain numerous discontinuous mudstone intervals (informally termed "shales") which in certain reservoir scenarios (e.g. heavy oil, low pressures) will act as barriers or baffles to fluid flow, and therefore impact recovery (Ainsworth, 2010). Increased understanding of the origin and distribution of these shales can lead to predictive models for the subsurface and lead to improved reservoir management.

Wave-dominated, and wave-dominated fluvial influenced shallow-marine systems comprise a series of facies that pass seaward from sand-dominated foreshore, upper- and lower shoreface deposits into a heterolithic offshore transition zone. This in turn passes seaward into a muddominated offshore shelf deposit (Elliot, 1978; Clifton, 2006; Howell et al., 2008a). The dominant processes of sediment transport and deposition are associated with the action of fair-weather and storm waves. Sediment deposited within the shoreface is typically derived from wave-dominated deltaic systems which form localized mouth bar complexes where distributary channels reach the shorelines. These mouth bars are reworked and redeposited by wave action (e.g. Bhattacharya and Giosan, 2003). Overall wave-dominated shallow marine systems produce good quality, laterally extensive reservoir sandbodies. The best reservoirs occur in the foreshore and upper shoreface while moderate reservoir properties are typical for the finer grained, lower shoreface (e.g. Stephen et al., 2008; Sech et al., 2009; Jackson et al., 2009). The offshore transition zone may contribute heterolithic pay with moderate to poor reservoir properties and very poor vertical connectivity. Mouth bars are typically laterally restricted (Wellner et al., 2005) and pass into shorefaces. Distributary channels are commonly heterolithic or mud-filled, although sand-filled channels may also occur (Olariu and Bhattacharya, 2006).

Within wave-dominated shoreline reservoirs, a hierarchy of mudstone barriers and baffles exist at the parasequence, bedset and intra-bedset scale (Hampson et al., 2003; Ainsworth, 2010). Parasequences (sensu Van Wagoner et al., 1990) are the fundamental building blocks of shallow marine systems and comprise the principal correlation packages and flow units within shallow marine reservoirs (Larue and Legarre, 2004; Ainsworth, 2010). A parasequence is defined as a "relatively conformable succession of strata bounded by flooding surfaces" (Van Wagoner et al, 1990). In wave-dominated shallow-marine systems, these occur as upward shallowing successions which include sandy shoreface and foreshore deposits with good reservoir properties (Stephen et al., 2008). The bounding surfaces are regionally extensive and commonly overlain by offshore mudstones or offshore transition zone heteroliths that are associated with poorer properties (e.g. Van Wagoner, 1990). A 
parasequence is deposited during a discrete phase of shoreline progradation when sediment supply outpaces the rate of accommodation creation. The parasequence boundary is formed during transgression which occurs when the rate of accommodation creation temporarily exceeds the rate of sediment supply. This leads to a kilometer-scale landward dislocation of the shoreline, resulting in deposition of more distal deposits on top of more proximal deposits. The facies transition associated with parasequence boundaries commonly generates laterally-extensive barriers to fluid flow. These facies changes also provide a robust correlation tool for reservoir zonation, with allocyclic changes that are relatively easy to identify in well logs and are potentially imaged on seismic data in subsurface oil fields (Hodgetts and Howell, 2000; Hodgetts et al., 2001). They can therefore be modeled deterministically in reservoir modeling studies and will commonly form the basis for reservoir zonation. The flow properties at the parasequence scale are primarily governed by the parasequence stacking patterns (Ainsworth, 2010).

Bedsets (sensu van Wagoner et al., 1990) are thin (1-10 m) intra-parasequence cycles of upward-shallowing, progradational packages of sediment which show an apparent upwardshoaling succession of facies, commonly from offshore transition to lower-shoreface, and are abruptly overlain by more distal facies (Storms and Hampson, 2005; Sømme et al., 2008). The upper bounding surfaces dip gently paleo-seawards, and can be traced for many kilometers in that direction, but lose their character as they are truncated by upper shoreface deposits updip. The fundamental distinction between bedsets and parasequences is that bedsets are not associated with a landward dislocation of the shoreline. In individual vertical profiles (i.e. well logs) and small outcrops the two may be difficult to distinguish.

Bedset boundaries can be generated by a number of different mechanisms. Minor rises in relative sea-level, which cause shoreline trajectories to climb more steeply, will lead to a change in facies stacking in the lower shoreface and offshore transition zone, without dislocating the shoreline landward (Hampson and Storms, 2003; Storms and Hampson, 2005). Local changes in wave regime or changes in sediment supply, often caused by avulsion of rivers feeding sediment to the shoreline, will also result in local disconformities that are not associated with a landward migration of the shoreline (Hampson and Storms, 2003; Storms and Hampson, 2005; Sømme et al., 2008; Sech et al., 2009). These discontinuities happen at a sub-regional scale and can potentially be correlated between wells within a single oilfield at standard well spacing (Sech et al., 2009). They may be visible in high-quality seismic data (Hodgetts and Howell, 2000). As will be demonstrated in this paper, the formation of bedset boundaries can also significantly impact the formation of the smallest level of heterogeneity, the "intrashoreface shales".

Intrashoreface shales are discontinuous mudstone beds occurring within the lower and, less commonly, upper shoreface intervals. In this study, the term is used for discontinuous mudstone beds occurring within the upper and lower shoreface, and within wave-dominated delta front deposits. The sandstones of the upper shoreface are predominantly deposited by the migration of nearshore bars and rip-channels, caused by fairweather waves and offshoredirected currents (Cliffton, 1976), while the lower shoreface is mainly composed of large, hummocky bedforms deposited under waning oscillatory flows during major storms (Dott 
and Bourgeois, 1982). The intrashoreface shales are most likely remnants of muddier riverderived fair-weather deposits in swales between bedforms and not eroded by fair-weather and storm waves. The intrashoreface shales are too small to be correlated between wells at oilfield scale (e.g. Zeito, 1965; Arnot, 2001), and have thus been termed "stochastic shales" because they are modeled probabilistically in reservoir modeling studies (Haldorsen and Lake, 1984).

The presence of intrashoreface shales may have a significant impact on fluid flow within reservoirs, as they will decrease vertical permeability and make flow paths more tortuous. This can lead to either improved or decreased recovery depending on the particular arrangement, geometry and distribution of baffles (Haldorsen et al., 1987). The inclusion of intrashoreface shales in reservoir models is limited because they have rarely been described or quantified in the published literature. Several studies have investigated shale lengths in different environments (Zeito, 1965; Arnott, 2001; Figure 1 in Burton and Wood, 2011). However, only a few studies have paid attention to details such as geometry, size range and how the intrashoreface shales are distributed within shallow-marine sedimentary systems (White and Willis, 2000; Burton and Wood, 2011). Such parameters are hard to collect using traditional field techniques, though helicopter-mounted lidar-scanning (Buckley et al., 2008a; Rittersbacher et al., 2013) allows for systematic collection of large volumes of spatially constrained data. The objectives of this paper are twofold: (1) to present a statistical documentation of intrashoreface shale distribution in wave-dominated, shallow marine systems; and (2) to discuss how architectural and paleogeographical aspects control the distribution of intrashoreface shales.

\section{Geological setting}

The studied outcrops are located in the Book Cliffs and the Wasatch Plateau in Central Utah, USA (Figure 1), and are part of the Campanian Blackhawk Formation and Star Point Sandstone (Figure 2) (Young, 1955). These units were deposited on the western side of the Western Interior Seaway of North America, which occupied the retroarc foreland basin of the Sevier Orogen. This orogeny was created by repeated accretion of island arc-systems and microcontinents during the subduction of the Farralon Plate under the North American Plate (Kaufman and Caldwell, 1993). The Star Point Sandstone and shallow-marine parts of the Blackhawk Formation were deposited as a series of mainly wave-dominated sandstone tongues prograding from the west into the basin, intercalated with deposits of the offshore Mancos Shale (Young, 1995). Sediments were supplied from the front of the Sevier Thrust to the shorelines via the fluvial systems of the continental part of the Blackhawk Formation, which transported sediment through up to $150 \mathrm{~km}$ of alluvial plain (e.g. Hampson et al., 2012). The shallow-marine deposits of the Star Point Sandstone and Blackhawk Formation can be traced from their most landward extent near the town of Emery, Utah, to the most basinward extent east of the town of Grand Junction, Colorado. The Star Point Sandstone is of Santonian to Campanian age, and the Blackhawk Formation is of Campanian age (Fouch et al., 1983). The area had a warm and humid climate at a paleolatitude of approximately $40^{\circ}$ N (Kauffman and Caldwell, 1993, Davies et al., 2005; Davies et al., 2006). 


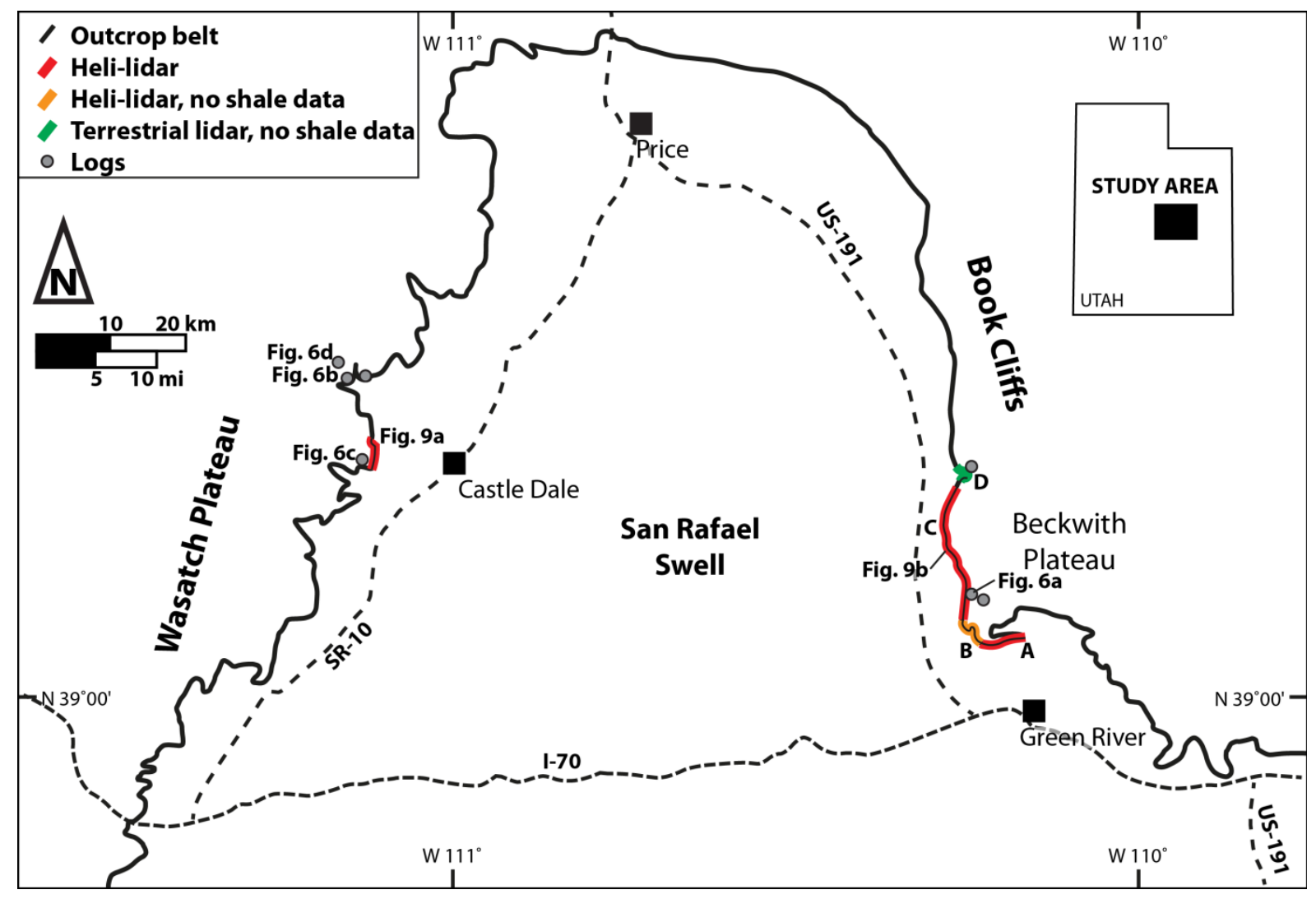

Figure 1. Map of the study area, showing the location of lidar scans and measured sections used in this study. Inset shows the location of the study area in the state of Utah. Interpreted lidar models are shown in Figure 10, and a selection of stratigraphic logs are shown in Figure 8.

Data for the current study are taken from the Book Cliffs and Wasatch Plateau outcrops on the edge of the San Rafael Swell in Utah (Figure 1). The current work has concentrated on the Kenilworth K4 parasequence (of Taylor and Lovell (1995); termed KPS 7 and 8 by Pattison (1995)) and the Storrs Ksp010 parasequence (Hampson et al., 2011). For each area, oblique helicopter-mounted lidar scanning (heli-lidar) has been used to obtain virtual outcrop (VO) models of the parasequences, in addition to supporting logs. The first virtual outcrop captures part of the Kenilworth Member of the Blackhawk Formation in the Beckwith Plateau between Woodside Canyon and the town of Green River. The Kenilworth K4 parasequence records approximately $9 \mathrm{~km}$ of shoreline progradation towards the east, and has an orientation of NNE-SSW in the Beckwith Plateau (Taylor and Lovell, 1995). The Kenilworth K4 parasequence has a sharp-based shoreface in the area near Battleship Butte, and also several incising channels on the top of the parasequence. This has been used as evidence for forced regression caused by a fall in relative sea-level (Ainsworth and Pattison, 1994; Pattison, 1995; Taylor and Lovell, 1995; Hampson and Storms, 2003; Howell and Flint 2003). Hampson and Storms (2003) reconstructed a sea-level curve for this interval based on interpreted shoreface-shelf profiles, and Storms and Hampson (2005) used this parasequence to compare with forward stratigraphic modeling of how prograding wave-dominated systems respond to allogenic and autogenic factors. 
The second virtual outcrop model is of the Ksp010 parasequence of the Storrs Tongue of the Star Point Sandstone (Flores et al., 1984; Hampson et al., 2011; Hampson et al., 2012), in the area west of the town of Castle Dale (Figure 1). The shorelines in the Storrs Tongue mainly consists of shorefaces, but, but have abundant distributary channels on top, and contains locally developed deltas (Flores, 1984; Hampson et al., 2012).

\section{Dataset and methods}

The dataset used in this study consist of two heli-lidar models (Buckley et al., 2008a; Rittersbacher et al., 2013) and one terrestrial lidar model (Bellian et al., 2005; Pringle et al., 2006). The helicopter-derived data was acquired using the Helimap System (Vallet and Skaloud, 2004; Buckley et al., 2008a); while the terrestrial data were collected using a Riegl Z420i laser scanner with a mounted Nikon D200 digital camera, as described by Buckley et al. (2010). The first heli-lidar model and the terrestrial lidar model cover the southern and eastern faces of the Beckwith Plateau in the Book Cliffs (Figure 1). The heli-lidar virtual outcrop is approximately $27 \mathrm{~km}$ long, roughly horseshoe-shaped and goes from Battleship Butte north of the town of Green River to the mouth of Woodside Canyon, while the terrestrial lidar model extends this area around $1 \mathrm{~km}$ further into Woodside Canyon (Figure 1). The virtual outcrop models sample the stratigraphy from the distal parts of the Kenilworth K2 parasequence to the Castlegate Sandstone (Figure 2). The southernmost $6 \mathrm{~km}$ of the model is oriented approximately parallel to depositional dip of the Kenilworth $\mathrm{K} 4$ parasequence, the following $16 \mathrm{~km}$ is parallel to depositional strike, and the northernmost 5 $\mathrm{km}$ is around $45^{\circ}$ oblique to depositional dip (Taylor and Lovell, 1995). Most of the outcrops are effectively inaccessible, though three sedimentary logs with a total length of $134 \mathrm{~m}$ were obtained from outcrops just behind the scanned cliffs (Figure 1).

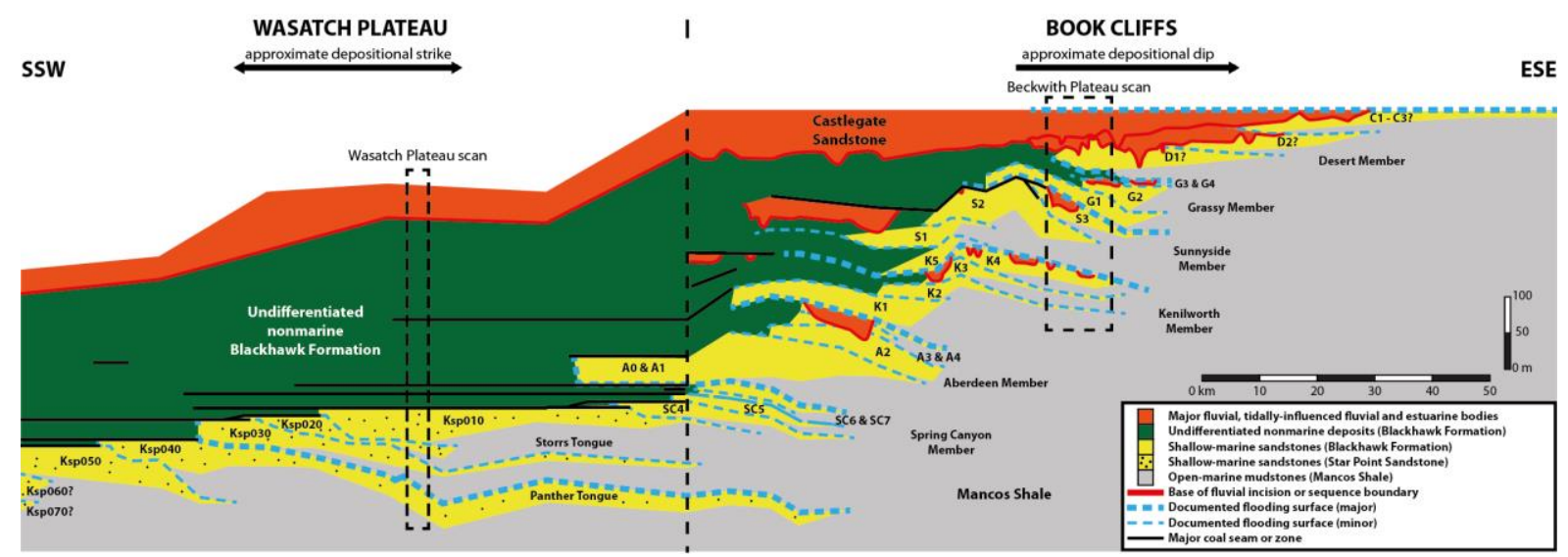

Figure 2. Summary stratigraphic cross-section through the Star Point Sandstone, Blackhawk Formation and lower Castlegate Formation in the Wasatch Plateau (left) and the Book Cliffs (right). Stippled rectangles show the location of the study areas. Kenilworth K4 ('K4') and Storrs KSP010 are the studied parasequences (after Hampson et al., 2012).

The second heli-lidar model of the Ksp010 parasequence covers a $3.3 \mathrm{~km}$ long section of the eastern cliff-face below North Horn Mountain, $10 \mathrm{~km}$ due west of the town of Castle Dale (Figure 1). It samples the stratigraphy from the shallow-marine Storrs Tongue from Ksp040 
to Ksp010 (Figure 2). The scanned outcrop is oriented N-S, at an angle of $60^{\circ}$ to the NW-SEtrending paleoshoreline (Flores et al., 1984; Hampson et al., 2011). The scan of the Ksp010 parasequence is supported by an $82 \mathrm{~m}$ long log, taken $500 \mathrm{~m}(1640 \mathrm{ft})$ behind the scanned outcrop since the outcrop itself is vertical and inaccessible (Figure 1). 4 additional logs were taken further to the north to investigate specific sedimentary facies.

Only the Kenilworth K4 and the Storrs Ksp010 parasequences were used to study the distribution of intrashoreface shale, chosen because of the high-quality, large exposures that have been comprehensively studied by previous workers and hence are well understood, and because the top of the shoreface is preserved along the entire outcrop belt. This surface was required as a datum for referencing the vertical position of the shale beds within the shoreface.

\section{Lidar Data collection and processing}

The detailed workflow of collecting and processing lidar data captured obliquely from a helicopter is described by Buckley et al. (2008a) and Rittersbacher et al. (2013), while processing and visualization of lidar data in general are described by Bellian et al. (2005), Pringle et al. (2006), Enge et al. (2007) and Buckley et al. (2008b). A brief summary is given below.

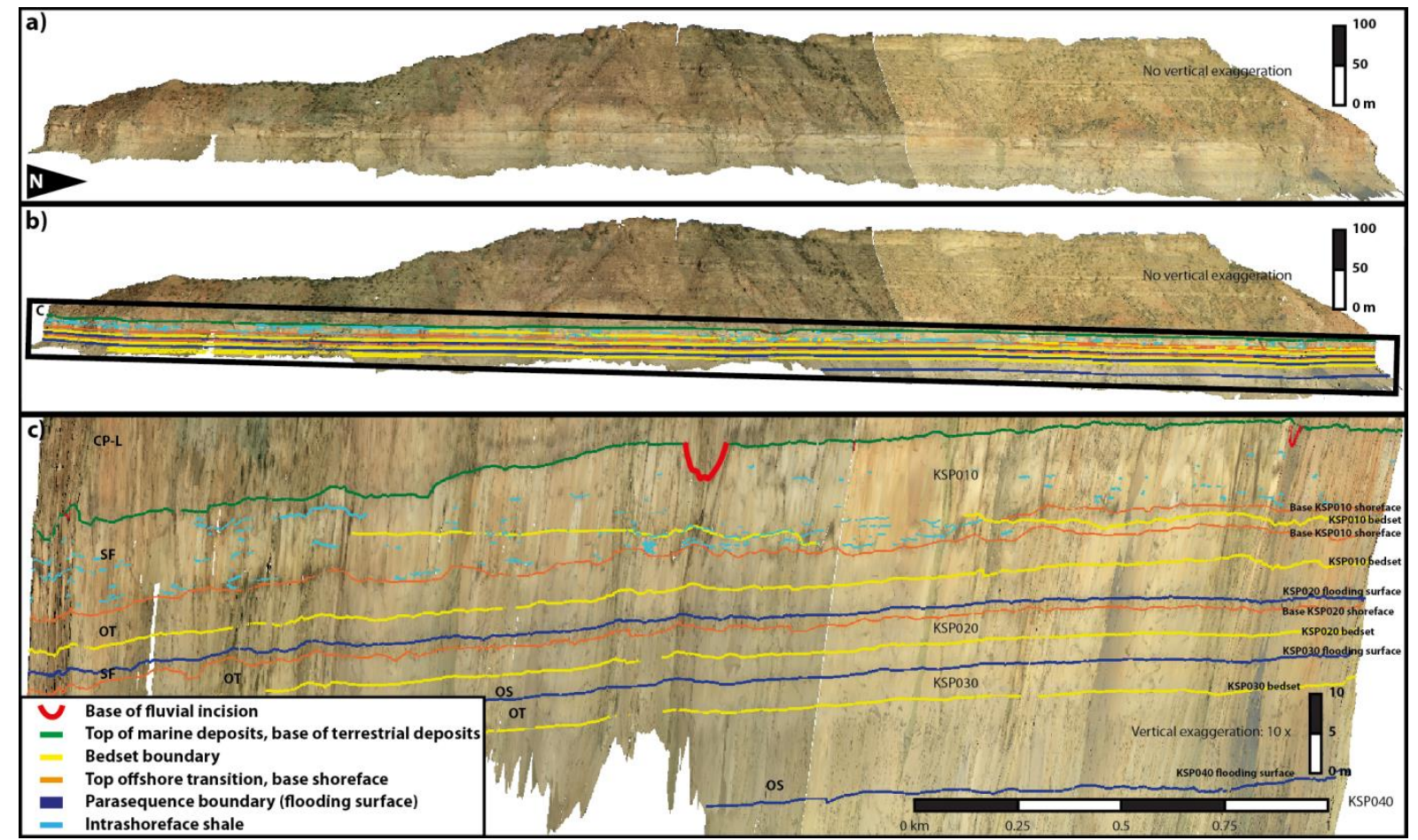

Figure 3. Data examples from the virtual outcrop in the Wasatch Plateau. Uninterpreted (a) and interpreted (b) models with no vertical exaggeration, and interpreted model of the marine deposits with 10x vertical exaggeration (c). For location, see Figures 1 and 2. Detailed interpretation in Figure 10a.

The lidar system works by sending out a laser beam to the outcrop and recording the time-offlight of the beam to obtain a distance measurement. The location of the measured point is 
calculated by using this distance, the direction of the laser beam, and the location of the scanner itself, which is obtained by differential Global Navigation Satellite System (GNSS) measurements and an inertial navigation system. The laser beam is emitted thousands of times per second, and a point cloud with xyz-positions of the outcrop surface is collected. Digital photographs are acquired simultaneously by a camera mounted on the scanning frame, and the location and orientation of the camera is recorded relative to the laser scanner. During the current study the distance between the outcrop face and the helicopter while

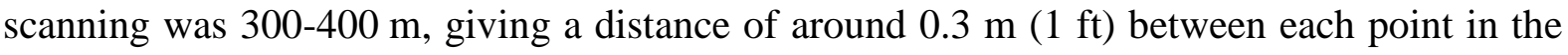
point cloud, and a pixel resolution of around $7 \mathrm{~cm}$ for the images.

In order to combine the geometrical measurements of the outcrop surface and the images, the collected data must be processed. The first step is to filter the point cloud to remove nonoutcrop points and to ensure a near-uniform point distribution. The second step is to triangulate the point cloud to create a $3 \mathrm{~d}$ model. Finally, the images were textured onto the surface of the 3D model using the known position and orientation obtained from the GNSS and inertial data. The result is a textured, photorealistic virtual outcrop model (Figure 3) that can be viewed on a desktop computer. Interpretations of stratigraphic surfaces and element geometries can be made directly on the model using in-house lidar interpretation software (LIME). Interpretation may be imported into reservoir modeling software, where surfaces, isopach maps and reservoir models can be generated.

\section{$\underline{\text { Virtual outcrop interpretation }}$}

Interpretation of the outcrop models consisted of three steps: (1) Interpretation of the major stratigraphic boundaries, followed by the boundaries between different architectural elements. A facies scheme with nine architecture elements was created based on earlier work in the area and what was most practical for this dataset. The facies scheme is described later in the text and in Table 1. (2) Construction of diagrams to show the facies variability along the outcrop. This was done by exporting interpreted lines delineating facies boundaries to reservoir modelling software. The boundaries were used to create surfaces, which in turn were used to make isopach maps of the different facies. The thickness of each facies was measured at $100 \mathrm{~m}$ intervals and imported into spreadsheets to create plots and graphs. The flooding surfaces on top of the Kenilworth K4 parasequence and the Storrs Ksp020 parasequence were used as datum surfaces in each of the two outcrops. (3) The last step was interpretation of intrashoreface shales (Figures 4 and 5). Three parameters were measured: the length (vertical distance from tip to tip), the depth (vertical distance from top of shoreface to the center of the shale) and the location (horizontal distance from end of outcrop).. The thickness of the shales is generally at or very close to the resolution of the image- and lidar data $(\mathrm{c} .7 \mathrm{~cm})$, and shale thickness could therefore not be measured. These measurements were imported into spreadsheets.

In order to quantify the variation in the number of shales along the outcrops, the outcrops were divided into $100 \mathrm{~m}$ long sections and the cumulative length of intrashoreface shales within each of the sections was calculated (Figure 6). This gives a measure for the length of 
Table 1: Summary descriptions of sedimentological properties and weathering characteristics of the studied architectural elements. Width of features refers to distances measured along the shoreline; length refers to distance measured perpendicular to the shoreline.

\begin{tabular}{|c|c|c|c|c|c|}
\hline $\begin{array}{l}\text { Sedimentary } \\
\text { environment }\end{array}$ & $\begin{array}{l}\text { Architectural } \\
\text { element }\end{array}$ & Lithology and sedimentary structures & Appearance in virtual outcrops & Process interpretation & Dimensions \\
\hline \multirow[t]{2}{*}{ Coastal plain } & $\begin{array}{l}\text { Coastal plain- } \\
\text { lagoon (CP-L) }\end{array}$ & $\begin{array}{l}\text { Laminated carbonaceous mudstone beds with abundant plant } \\
\text { fragments; }<0.5 \mathrm{~m} \text { thick coal beds not underlain by rooted intervals; } \\
\text { thin }(1-20 \mathrm{~cm}) \text { sandstone beds with wave-ripples and occasional } \\
\text { wavy bedding. See Figure } 8 \mathrm{a} \text {. }\end{array}$ & $\begin{array}{l}\text { Slope-forming beige to brown mudstone with } \\
\text { laterally continuous coal beds and occasional resistant } \\
\text { sandstone beds (Figure } 7 \mathrm{a} \text { ). }\end{array}$ & $\begin{array}{l}\text { Carbonaceous mudstone indicates a quiet, dysaerobic } \\
\text { environment, coals are probably ex situ due to lack of roots. } \\
\text { Occasional wave-ripples indicate standing water with } \\
\text { occasional wave-reworking. Sandstone beds are overbank } \\
\text { deposits, wash-over-fans or possibly lagoon-head deltas. }\end{array}$ & $\begin{array}{l}\text { length: }>1.8 \mathrm{~km} \\
\text { width: }>17.4 \mathrm{~km} \\
\text { thickness: } 0-6 \mathrm{~m}\end{array}$ \\
\hline & $\begin{array}{l}\text { Distributary } \\
\text { channel (DC) }\end{array}$ & $\begin{array}{l}\text { Sandy type: Erosive base with coarse sand and quartzite pebbles. } \\
\text { Very fine- to medium-grained sandstone beds with trough and planar } \\
\text { cross-bedding and planar-parallel stratification. Occasional rip-up } \\
\text { clasts. See Figure } 8 \text { b. } \\
\text { Muddy type: Not logged. }\end{array}$ & $\begin{array}{l}\text { Channelized incisions into the SF and DF deposits. } \\
\text { Sandy channels recognizable by underlying erosion } \\
\text { surface and subtle color changes. Mudstone- and } \\
\text { heterolith-filled channels occur as recessive, covered } \\
\text { incisions into the shoreface and delta front sandstone } \\
\text { (Fig. 3c). }\end{array}$ & $\begin{array}{l}\text { Interpreted as terminal distributary channels (Olariu \& } \\
\text { Bhattacharya, 2006), feeding the delta front (DF) deposits they } \\
\text { incise into, or deltas further seawards in case of channels } \\
\text { incising into shoreface (SF) deposits without any fluvial } \\
\text { influence. Muddy channels are most common, believed to form } \\
\text { as channel mouths are plugged by longshore drift of sand. }\end{array}$ & $\begin{array}{l}\text { width: } 27-435 \mathrm{~m} \text { (apparent) } \\
\text { thickness: } 3-8 \mathrm{~m} \\
\text { width/thickness: } 7.2-54 \\
\text { number of observations: } 9\end{array}$ \\
\hline \multirow[t]{5}{*}{$\begin{array}{l}\text { Wave-dominated } \\
\text { shoreline-shelf }\end{array}$} & Shoreface (SF) & $\begin{array}{l}\text { Foreshore (FS): Rooted, parallel-laminated or low-angle cross } \\
\text { bedded very fine- to fine-grained sandstone } \\
\text { Upper shoreface (USF): Trough- and planar cross-stratification, } \\
\text { planar-parallel-laminated very fine to fine-grained sandstone. } \\
\text { Lower shoreface (LSF): Amalgamated hummocky-cross stratified, } \\
\text { planar-parallel laminated and wave-rippled sandstone beds. See } \\
\text { Figure 8c. }\end{array}$ & $\begin{array}{l}\text { Resistant, beige to white, massive to rugose near- } \\
\text { vertical cliffs (Figure } 7 \mathrm{~b} \text {, c). Occasional recessed } \\
\text { beds. Bedset-bounding clinoforms dip c. } 0.5^{\circ} \\
\text { plaeoseaward. Internal facies associations (FS, USF } \\
\text { and LSF) cannot be defined in virtual outcrops. }\end{array}$ & $\begin{array}{l}\text { Interpreted as prograding strandplains fed by longshore drift. } \\
\text { FS: Subaerial sheet-floods by breaking waves. } \\
\text { USF: Migration of coastal dunes and rip channels during fair- } \\
\text { weather conditions (e.g. Clifton, 2006). } \\
\text { LSF: Mainly storm-deposited or storm-reworked beds (e.g. Dott } \\
\text { and Bourgeois, 1982; Clifton, 2006). }\end{array}$ & $\begin{array}{l}\text { length: }>5.6 \mathrm{~km} \\
\text { width: }>20.4 \mathrm{~km} \\
\text { thickness: } 15-36 \mathrm{~m}\end{array}$ \\
\hline & $\begin{array}{l}\text { Wave- } \\
\text { dominated } \\
\text { delta-front } \\
\text { (DF) }\end{array}$ & $\begin{array}{l}\text { Very fine- to fine-grained sandstone with through cross- } \\
\text { stratification, planar-parallel stratification, convolute lamination. } \\
\text { Abundant coaly foreset drapes, plant fragments and rip-up clasts. } \\
\text { Hummocky cross-stratification in the lower part. See Figure 8d. }\end{array}$ & $\begin{array}{l}\text { Resistant, beige, massive to rugose near-vertical cliffs } \\
\text { with abundant, c. } 2^{\circ} \text { dipping (in dip section) or } \\
\text { convex upwards (in strike section), muddy clinoforms } \\
\text { (Figure 7a). Always overlain by distributary channels } \\
\text { (DC). }\end{array}$ & $\begin{array}{l}\text { Convolute bedding indicate rapid deposition (Collinson et al., } \\
\text { 2006), abundant terrestrial derived material and rip-up clasts } \\
\text { indicate a terrestrial sediment source, steeper delta clinoforms } \\
\text { indicates more mud supplied by rivers than adjacent SF } \\
\text { environment (Bhattacharya and Olariu, 2006). High proportion } \\
\text { of wave-generated structures leads to an interpretation as a } \\
\text { wave-dominated delta front. }\end{array}$ & $\begin{array}{l}\text { width: c. } 1 \mathrm{~km} \\
\text { thickness: } 18-27 \mathrm{~m}\end{array}$ \\
\hline & $\begin{array}{l}\text { Intrashoreface } \\
\text { shales (ISS) }\end{array}$ & $\begin{array}{l}\text { Wavy- to lenticular-bedded sandy carbonaceous siltstone beds which } \\
\text { occur within the shoreface (SF) and delta front (DF) (Figures } 5 \text { and } \\
\text { 8d). Generally } 2.5-15 \mathrm{~cm} \text { thick. }\end{array}$ & $\begin{array}{l}\text { Discontinuous recessive breaks in SF and DF (Figure } \\
\text { 4). }\end{array}$ & $\begin{array}{l}\text { River-derived material deposited in lee of bars or during fair- } \\
\text { weather periods which were not eroded by subsequent storm or } \\
\text { fair-weather processes. }\end{array}$ & $\begin{array}{l}\text { length: } 2-101 \mathrm{~m} \\
\text { width: } 3-186 \mathrm{~m} \\
\text { thickness: } 2.5-15 \mathrm{~cm} \\
\text { number of observations: } 921\end{array}$ \\
\hline & $\begin{array}{l}\text { Offshore } \\
\text { transition (OT) }\end{array}$ & $\begin{array}{l}\text { Very fine- to fine-grained, hummocky cross-stratified, planar- } \\
\text { parallel stratified and wave-rippled sandstone beds interbedded with } \\
\text { bioturbated sandy siltstone beds (Figure 8c). A general upwards } \\
\text { increase in sandstone content. }\end{array}$ & $\begin{array}{l}\text { Resistant, cliff-forming to covered interbedded } \\
\text { sandstone and mudstone beds (Fig. } 7 \text { ). }\end{array}$ & $\begin{array}{l}\text { Sandstone beds are interpreted to be storm-beds deposited under } \\
\text { waning combined flows during storms, mudstone deposits are } \\
\text { interpreted to be fair-weather deposits (Elliott, 1978). Forms } \\
\text { below mean storm-wave-base. }\end{array}$ & $\begin{array}{l}\text { length: }>5.6 \mathrm{~km} \\
\text { width: }>20.4 \mathrm{~km} \\
\text { thickness: } 0-20 \mathrm{~m}\end{array}$ \\
\hline & $\begin{array}{l}\text { Subaqueous } \\
\text { channels (SC) }\end{array}$ & Not logged & $\begin{array}{l}\text { Channelized incisions occurring within OT, often } \\
\text { incising into underlying } \mathrm{SF} \text { ( } \mathrm{Fig} 7 \mathrm{c} \text { ). Muddy to } \\
\text { heterolithic fill. }\end{array}$ & $\begin{array}{l}\text { Subaqueous channels cut and filled by hyperpycnal flows from } \\
\text { distributary channels further up-dip. Feeds shelf turbidite } \\
\text { systems further down-dip (Pattison et al., 2007). }\end{array}$ & $\begin{array}{l}\text { width: } 67-705 \mathrm{~m} \text { (apparent) } \\
\text { thickness: } 4-11 \mathrm{~m} \\
\text { number of observations: } 6\end{array}$ \\
\hline Offshore shelf & Offshore (OS) & $\begin{array}{l}\text { Light grey, intensely bioturbated sandy siltstone with sparse, thin, } \\
\text { bioturbated sandstone beds with hummocky cross-stratification or } \\
\text { wave-ripples (Figure 8d). }\end{array}$ & $\begin{array}{l}\text { Mainly scree-covered, slope forming unit, visible as } \\
\text { light grey massive mudstone with sparse, horizontal } \\
\text { sand beds in resistant headlands. }\end{array}$ & $\begin{array}{l}\text { Interpreted to have settled from suspension in an oxic shelf } \\
\text { environment with little wave-energy. Thin sand-beds are } \\
\text { interpreted to represent extreme storms. }\end{array}$ & \\
\hline Transgressive lag & $\begin{array}{l}\text { Trans-gressive } \\
\text { lag (LAG) }\end{array}$ & $\begin{array}{l}\text { Medium- to coarse-grained sandstone with abundant shell-fragments } \\
\text { and bioturbation index 5-6. Overlies CP-L and SF in Kenilworth K4 } \\
\text { parasequence, and underlies OS (Figure 8a). }\end{array}$ & $\begin{array}{l}\text { Resistant sandstone bed between slope-forming CP-L } \\
\text { and OS, not visible when overlying SF. }\end{array}$ & $\begin{array}{l}\text { Sediment reworked by waves during flooding and transgression } \\
\text { of the K4. }\end{array}$ & $\begin{array}{l}\text { length: }>5.6 \mathrm{~km} \\
\text { width: }>20.4 \mathrm{~km} \\
\text { thickness: } 0.2-2 \mathrm{~m}\end{array}$ \\
\hline
\end{tabular}


intrashoreface shale in each section of the outcrop in cumulative shale length per $100 \mathrm{~m}$. Average shale length per $100 \mathrm{~m}$ and number of shales per $100 \mathrm{~m}$ was also plotted.

It is not possible to measure grain size directly from the outcrop models. Therefore, a key assumption of this work is that recessive breaks in the shoreface with discrete ends are intrashoreface shales (Figure 4). This is supported by observations in the field which illustrate that these breaks are associated with weathering of fine grained (siltstone and claystone) intervals. However, it is possible that not all weathering breaks are associated with shales and as such this study may overestimate their frequency.

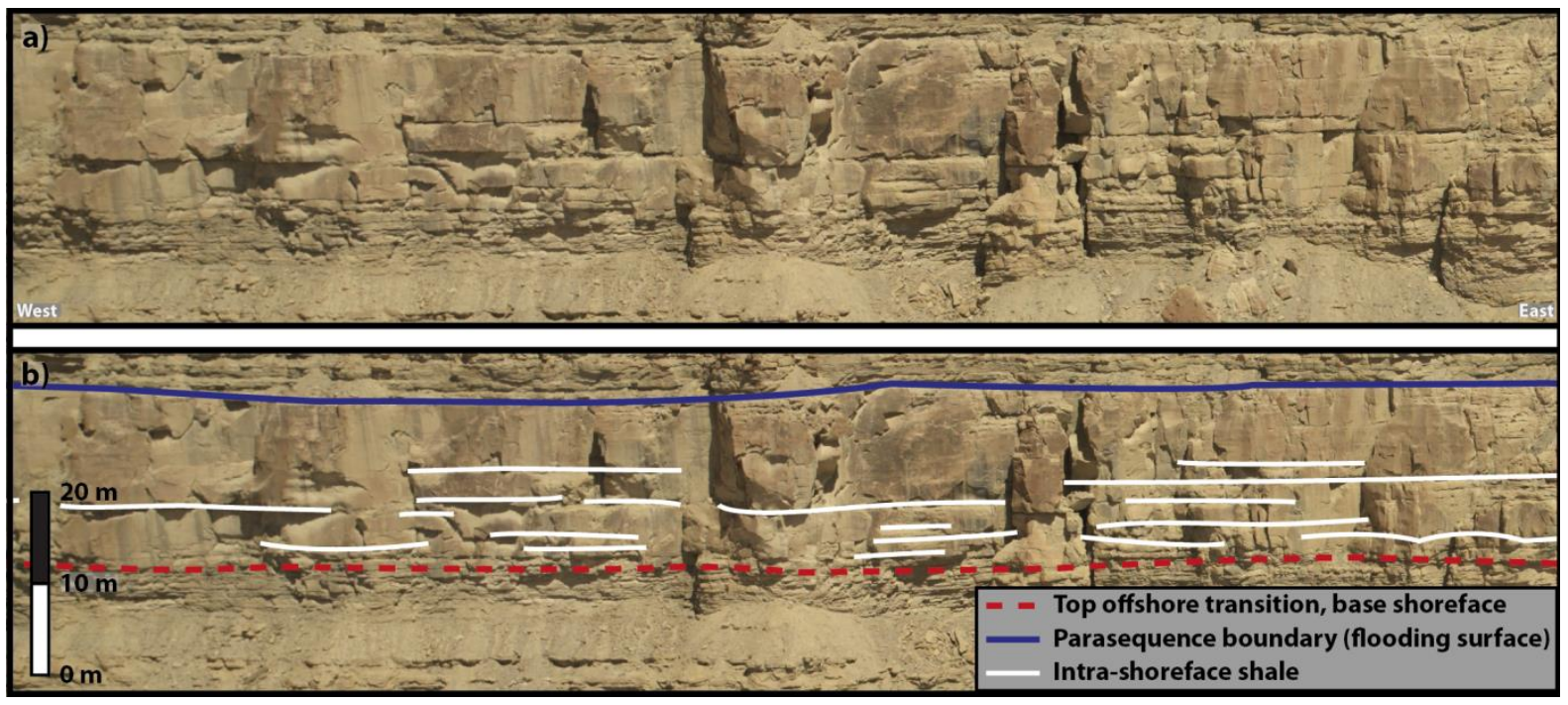

Figure 4. Uninterpreted (a) and interpreted (b) examples of intra-shoreface shales from the Sunnyside Member of the Blackhawk Formation from virtual outcrop data. Note the downwards increase in amount of mudstones, and the discrete tips of each mudstone body.

\section{Results}

\section{$\underline{\text { Architectural elements and their distribution }}$}

\section{Architectural elements and depositional environments}

Lithology was interpreted in the virtual outcrops based on the weathering characteristics of the scanned cliff-face (Figure 7). Sandstone is visible as beige, resistant beds and cliff-faces. Mudstone is often slope-forming and covered, but occurs as gray cliff-faces in resistant headlands, or recessed linear features in the case of thin mudstone beds in sandstone bodies. Interbedded sand- and mudstone beds occur in weathered cliff faces as resistant, beige sandstone ledges and darker, recessed mudstone intervals. Coals occur as dark gray to black beds. There is generally an excellent correspondence between predicted lithology from the virtual outcrops and actual lithology observed in the field.

Most of the studied outcrops occur as vertical cliffs, and are therefore inaccessible to traditional outcrop description. A facies scheme based on the weathering profiles of the sedimentary rocks has therefore been created (Table 1). This is more applicable when using virtual outcrop data, because properties such as grain size, sedimentary structures and texture 
cannot be measured in the virtual outcrops. The weathering profiles give an acceptable approximation to the sedimentary facies in wave-dominated deposits (Hampson et al., 2011).

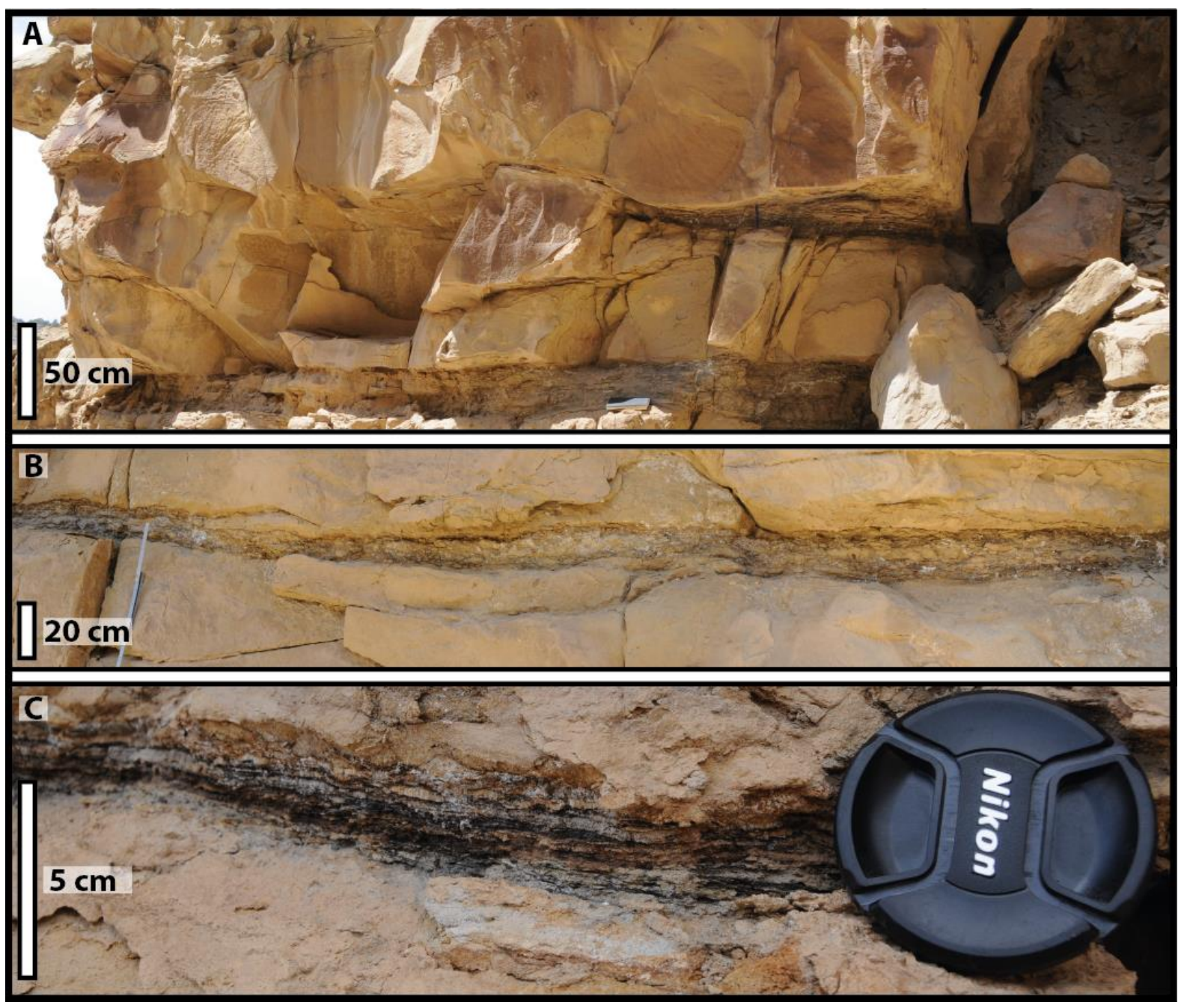

Figure 5. Examples of discontinuous intra-shoreface shales from the Sunnyside Member of the Blackhawk Formation. a) $15 \mathrm{~cm}$-thick discontinuous bed (white triangles) of interlaminated carbonaceous shale and sand lenses near the base of the lower shoreface deposits of the Sunnyside S3 parasequence. The bed pinches out to the left, and becomes covered to the right. b) $15 \mathrm{~cm}$-thick bed of wavy bedded carbonaceous shale and sandstone in the Sunnyside S2 parasequence. c) $2.5 \mathrm{~cm}$ thick discontinuous bed consisting of interlaminated carbonaceous shale and thin sand lenses, located in the lower shoreface of the Sunnyside S2 parasequence.

The studied deposits have been divided into nine architectural elements based on appearance in the lidar data (Figure 7), and these have been calibrated to the field observations (Figure 8): (1) coastal plain/lagoon, (2) distributary channel, (3) shoreface, (4) intrashoreface shale, (5) wave-dominated delta front, (6) subaqueous channel, (7) offshore transition, (8) offshore shelf and (9) transgressive lag. The architectural elements are grouped into four sedimentary environments: (A) Coastal plain, (B) wave-dominated shoreline, (C) offshore shelf and (D) transgressive lag. Detailed descriptions of these elements are given in Table 1. 
Most of the architectural elements were investigated in outcrop and logged, but logs were generally not located on the scanned cliff-faces, since these are vertical and inaccessible. For most of the architectural elements, the logs are located just behind the scanned cliffs (Figure 1). However, no delta front (DF), distributary channel (DC) and subaqueous channel deposits (SC) could be accessed within the study area. Examples of delta front (DF) and a sand-filled distributary channel (DC) were logged in the Storrs Ksp010 approximately $10 \mathrm{~km}$ north of the lidar scan in the Wastach Plateau (Figure 1, Figure 8). No accessible examples of the subaqueous channels were found within the studied parasequences.

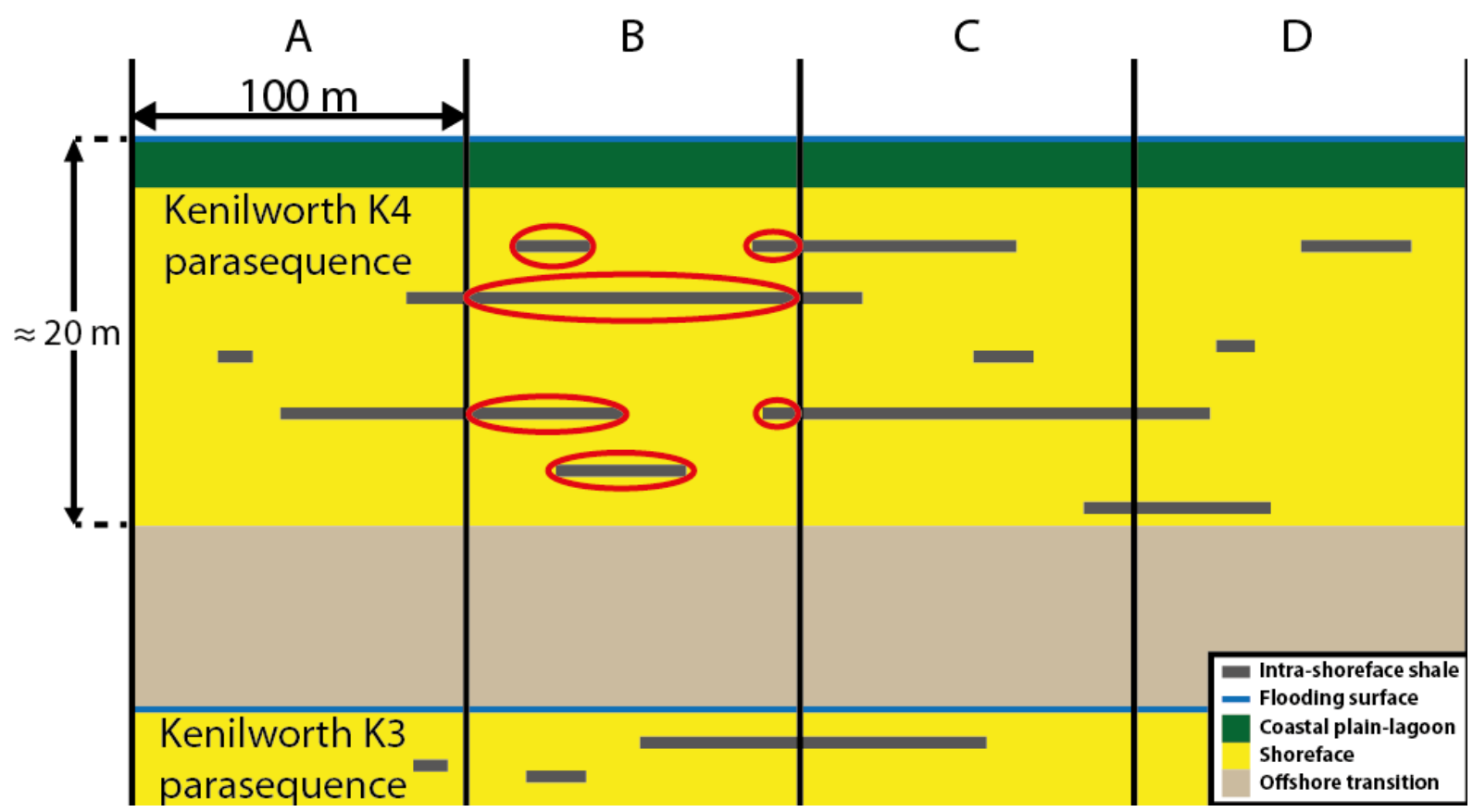

Figure 6. Illustration of how horizontal shale density is calculated. The outcrop is divided into $100 \mathrm{~m}$ long sections, and the cumulative length of shales within each section is calculated. The parts of shales within red ellipses are used to calculate the shale density in section B, which has a shale density of $230 \mathrm{~m}$ of shale per 100 $\mathrm{m}$ of outcrop.

The facies scheme used in this study is similar to the schemes used in other studies in the Blackhawk Formation (e.g. Van Wagoner, 1990; Howell and Flint, 2003; Hampson and Storms, 2003) and other wave-dominated systems, with some minor differences:

The shoreface is in studies based on sedimentological criteria commonly divided into four lithofacies associations, foreshore (FS), upper shoreface (USF), lower shoreface (LSF) and offshore transition zone (OT) (e.g. Howell and Flint, 2003; the terms proximal lower shoreface and distal lower shoreface are also used for lower shoreface and offshore transition zone by some authors, e.g. Hampson and Storms, 2003). The FS, USF and LSF mainly consist of amalgamated sandstone beds with minor amounts of internal discontinuous mudstone beds. It is not possible to separate between these facies in the virtual outcrop data, since all three occur as massive sandstone beds with occasional discontinuous mudstone beds. In this study, the FS, USF and LSF are treated as one architectural element termed shoreface (SF). Deposits of the offshore transition zone (OT) occur as interbedded 
hummocky cross-stratified sandstone and mudstones beds, and are easily distinguished from the overlying shoreface (Figure 7).

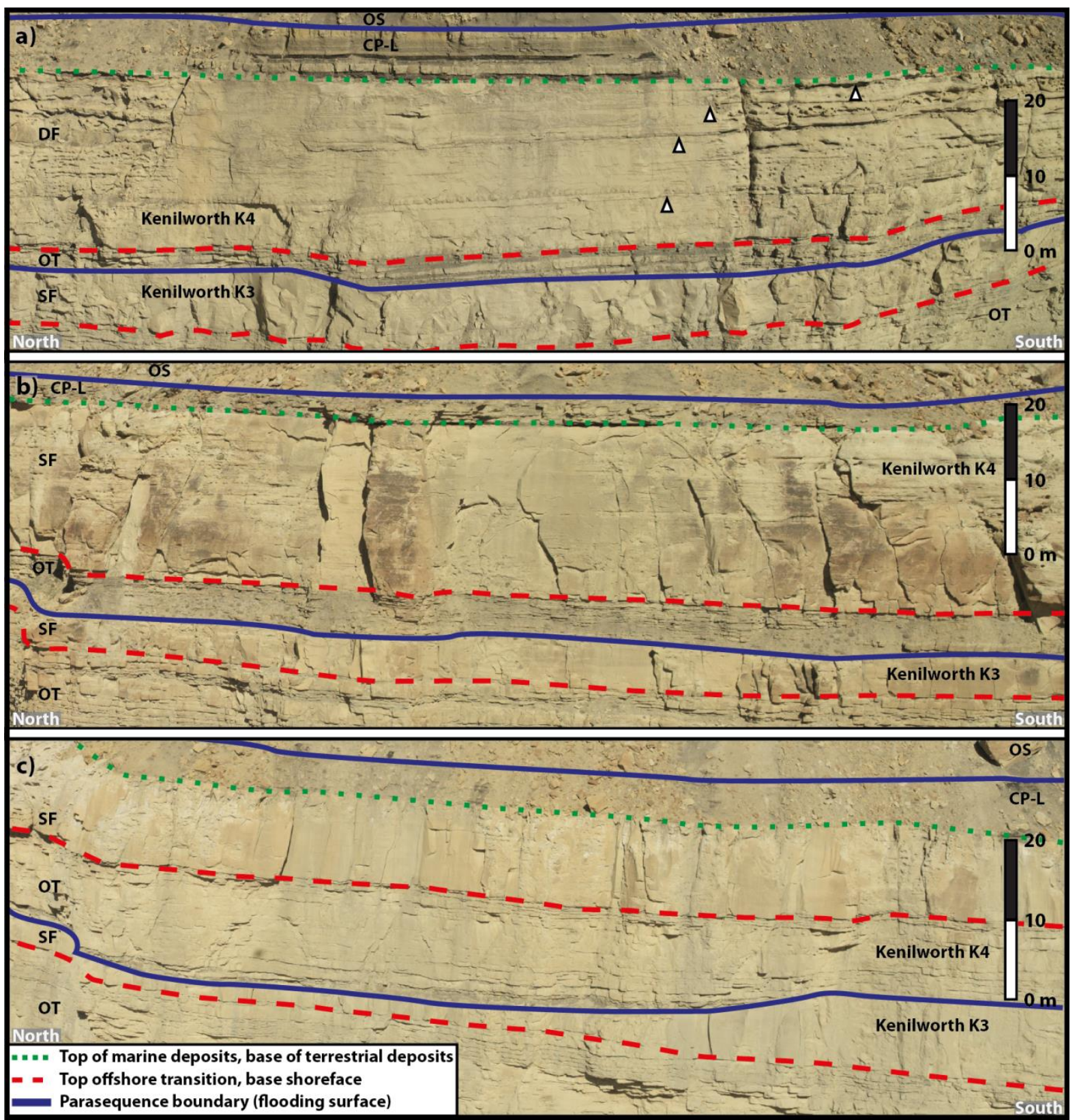

Figure 7. Appearance of architectural elements in the outcrop models. See Figure 10b for location of images. CP/L, Coastal plain/Lagoonal Lagoonal; DF, Delta front; SF, Shoreface; OT, Offshore transition; OS, Offshore shelf. A) Wave-dominated delta front in the Kenilworth 4 overlain by well-exposed lagoonal deposits. Note the long dipping muddy interbeds in the delta front marked by white triangles, and the coal beds in the coastal plain/lagoonal deposits. B) Wave-dominated shoreface in the Kenilworth 4. Note the sharp boundary between the amalgamated sand-beds of the shoreface and the interbedded sand and mud in the offshore transition. C) Margin of a subaqueous channel cutting down into the Kenilworth 3 parasequence. The channel appears to be filled with muddy deposits near the base, and offshore transition in the remaining parts.

The focus of this study is the size and distribution of discontinuous mudstone beds which occur within the otherwise sandy shoreface (SF) and wave-dominated delta-front (DF) sandstones, here termed intrashoreface shales (ISS). These occur as discontinuous, recessive 
breaks in the virtual outcrops (Figure 4). In outcrop they consist of wavy- to lenticularbedded, carbonaceous mudstone beds in outcrop, ranging in thickness from $2.5-15 \mathrm{~cm}$ (Figure 5). They are often present in depressions on top of beds, and partially eroded by overlying hummocky- and swaley-cross stratified sandstone beds. They are therefore interpreted as remains of fair-weather deposits partially eroded by strong waves during periodic storms. The abundant carbonaceous material is probably finely comminuted plant material derived from rivers, while the thin internal sandstone laminae may be wave-ripples. A detailed description of the geometries of 921 intrashoreface shales measured in the lidar models is presented below.
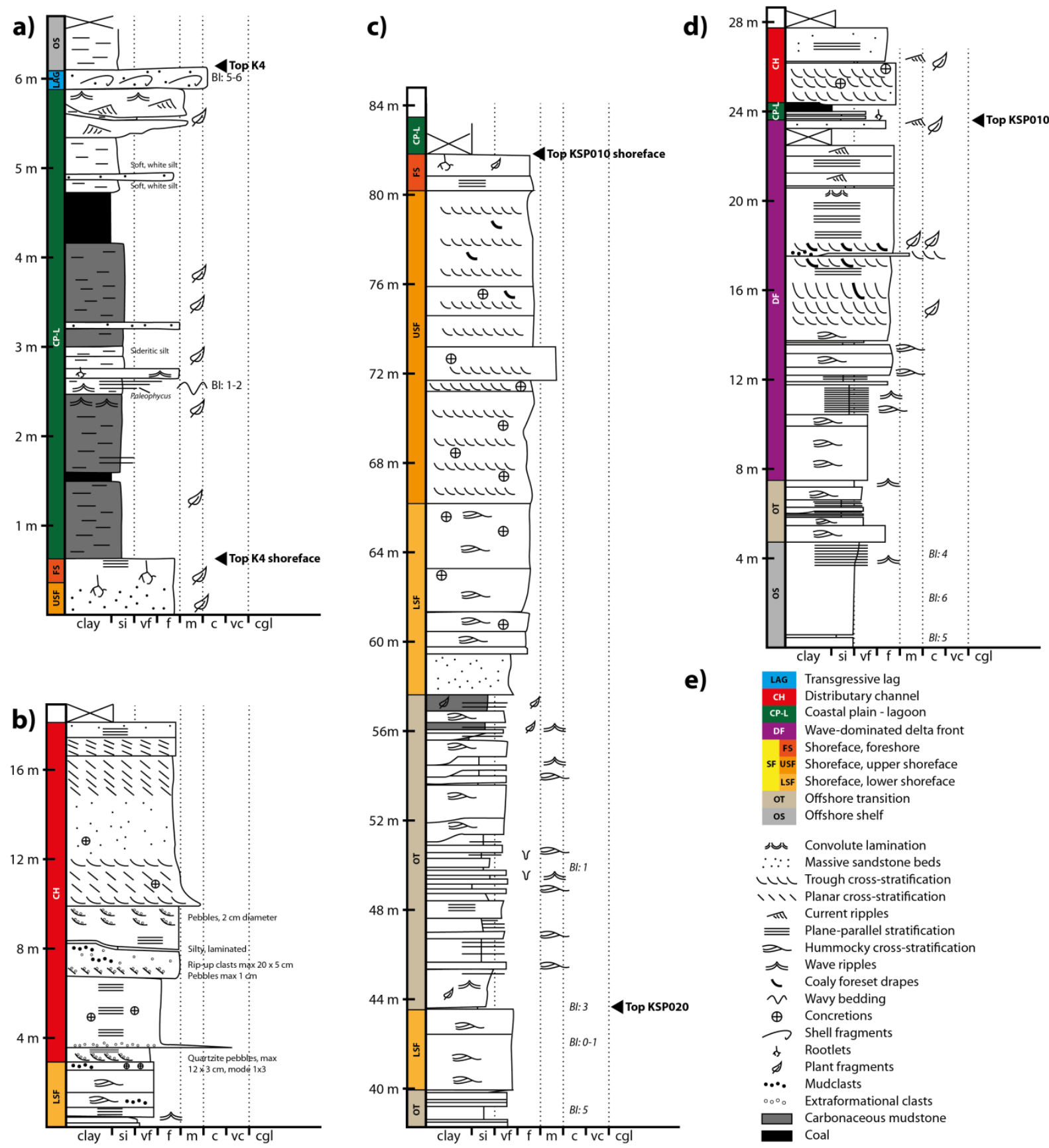

e)

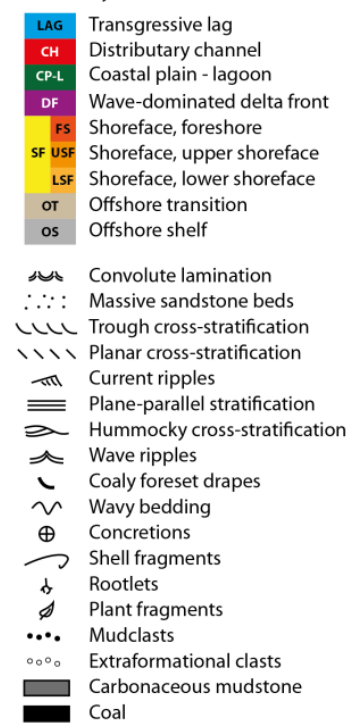

Figure 8. Stratigraphic logs illustrating facies and facies associations in the studied intervals. See Figures 1, 10a and $10 \mathrm{~b}$ for location. (a) Coastal plain/lagoonal architectural element on top of the Kenilworth K4 parasequence. 
Note that this $\log$ is on a smaller scale than the other logs. (b) Distributary channel in the top of the Storrs Ksp010 parasequence. (c) Shoreface and offshore transition deposits of the Storrs KSP010 and 020 parasequences. (d) Offshore, offshore transition, delta front and coastal plain deposits in the Storrs KSP010 parasequence. BI, Bioturbation Index (sensu Taylor and Goldring, 1993).

Six channelized incisions with a concave-up basal surface were observed in virtual outcrops in the offshore transition in the Kenilworth $\mathrm{K} 4$ parasequence. These erode into the top of the underlying Kenilworth K3 parasequence. The flanks of these channels are in some places seen to erode into with the surrounding offshore transition deposits, indicating that they are younger than the Kenilworth K3 parasequence. These channelized incisions are interpreted to be subaqueous channels, cut and filled by hyperpycnal flows from distributary channels updip and feeding shelf turbidite systems down-dip (Pattison et al., 2007). Further discussion about these channels is beyond the scope for this paper.

The studied deposits are interpreted to be the deposits of relatively linear, wave-dominated coastlines (e.g. Taylor and Lovell, 1995; Howell and Flint, 2003; Hampson and Howell, 2005). Shoreface deposits (SF) are believed to have received sediment mostly from longshore drift of sand derived from wave-reworking and winnowing of mouth-bars of locally developed wave- and river-dominated deltas (DF), which developed around localized fluvial input points (Bhattacharya and Giosan, 2003; Charvin et al., 2010). The subaerial expression of the shoreface deposits are believed to have been strandplains with linear beach ridges, while the coastal plain behind the DF are believed to have consisted of a distributary channel and arcutate beach ridges (e.g. Sømme et al., 2008)

\section{Datum selection}

A datum surface was required to plot the data from the three-dimensional outcrops on to a two-dimensional profile. For the Beckwith Plateau dataset, the flooding surface at the top of the Kenilworth K4 parasequence was used as a datum. The flooding surface on top of Ksp020 was used as a datum for the model for the Wasatch Plateau. Using the boundary between continental and shallow-marine deposits in the Storrs Ksp010 was attempted, but it became apparent that this is not a paleohorizontal surface, since flattening of this surface created an unrealistic topography on the underlying surfaces (Figure 9a). Using any of the flooding surfaces and bedset boundaries below the top of the Ksp010 surfaces produced better results and revealed a relatively complex topography at the top of the Ksp010 (Figure 9b). However, no datum surfaces are perfectly smooth and flat, and some amount of distortion is inevitable (Bhattacharya, 2011). Some of the high-frequency variability in the facies plots (such as the depression at $4.2 \mathrm{~km}$ at top the of the Kenilworth $\mathrm{K} 3$ parasequence, Figure 10b, $\mathrm{AB}$ ), is believed to be primarily caused by unevenness of the datum.

Facies Architecture in the Storrs Ksp010 parasequence

Figure 10a shows the distribution of architectural elements in the Storrs Ksp010 parasequence. The Storrs Ksp010 parasequence overlies a thin tongue of shoreface of the Ksp020 parasequence (Figure 8c), thinning from $5 \mathrm{~m}$ in the south to $1.5 \mathrm{~m}$ in the northern 
part of the outcrop model. This represents the distal parts of the Ksp020 shoreface, seen in a section oblique to dip.

The top of the Ksp020 is overlain by a package of offshore transition belonging to the Ksp010, thickening from $14 \mathrm{~m}$ in the $\mathrm{SW}$ to $17 \mathrm{~m}$ in the NE. This is further overlain by the shoreface of the Ksp010. This shoreface has a prominent bedset boundary in the NE part, where a c. $3 \mathrm{~m}$ thick tongue of shoreface sandstone is overlain by a c. $3 \mathrm{~m}$ thick wedge of offshore transition. The wedge of offshore transition pinches out towards the south after $2.3 \mathrm{~km}$, though the discontinuity continues as a NE-wards-dipping muddy clinoform visible from $1 \mathrm{~km}$ to 2 $\mathrm{km}$ in the model. The base of the shoreface of the northern bedset is c. $6 \mathrm{~m}$ higher than the southern. The abrupt superpositioning of offshore transition above shoreface deposits without evidence for landward translation of the shoreline is a bedset boundary (see above).

The top of the shoreface is irregular in the southernmost 0.5 $\mathrm{km}$ of the model (Figure 10a), possibly due to erosion or the
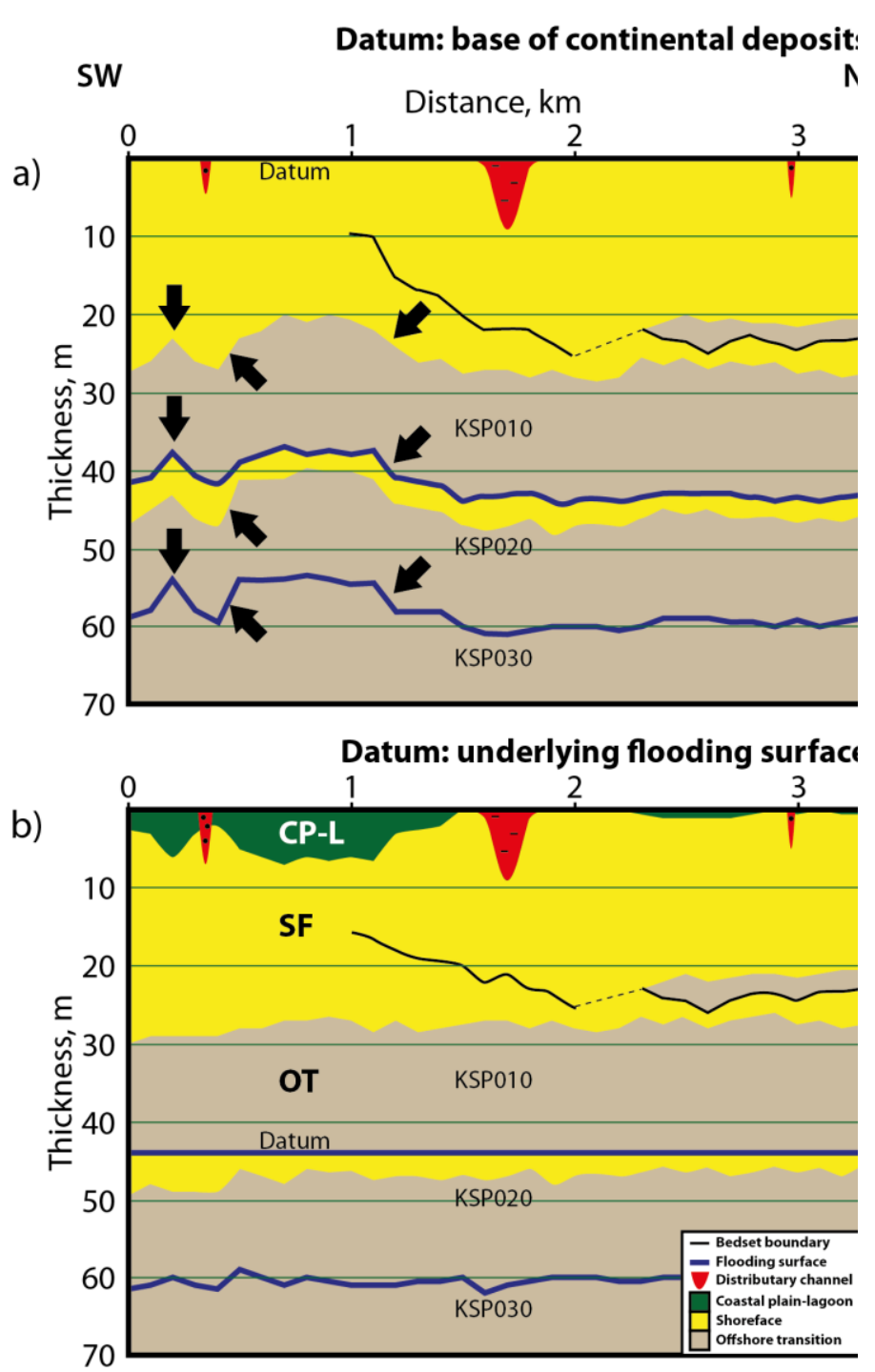

Figure 9. Figure illustrating the importance of selecting a correct datum when plotting results of three-dimensional lidar data onto a flat plane. Using an incorrect datum superimposes the topography of the datum surface to other layers (black arrows) resulting in an non-physical model, while using a paleohorizontal datum surface results in a reasonable geometry for all layers (b). presence of unidentified sand-filled channels. From 0.5 to $1.1 \mathrm{~km}$, the top of the shoreface makes a planar boundary with the overlying coastal plain deposits. Above the bedsetbounding clinoform, from 1.1 to $1.5 \mathrm{~km}$, the shoreface-coastal plain-boundary slopes upwards from $6.5 \mathrm{~m}$ depth to $0 \mathrm{~m}$ depth, and stays planar for the remainder of the model except for the distributary channel at $1.7 \mathrm{~km}$. This is similar to the relationship seen at the base of the shoreface of the Ksp010. 
a) WASATCH PLATEAU
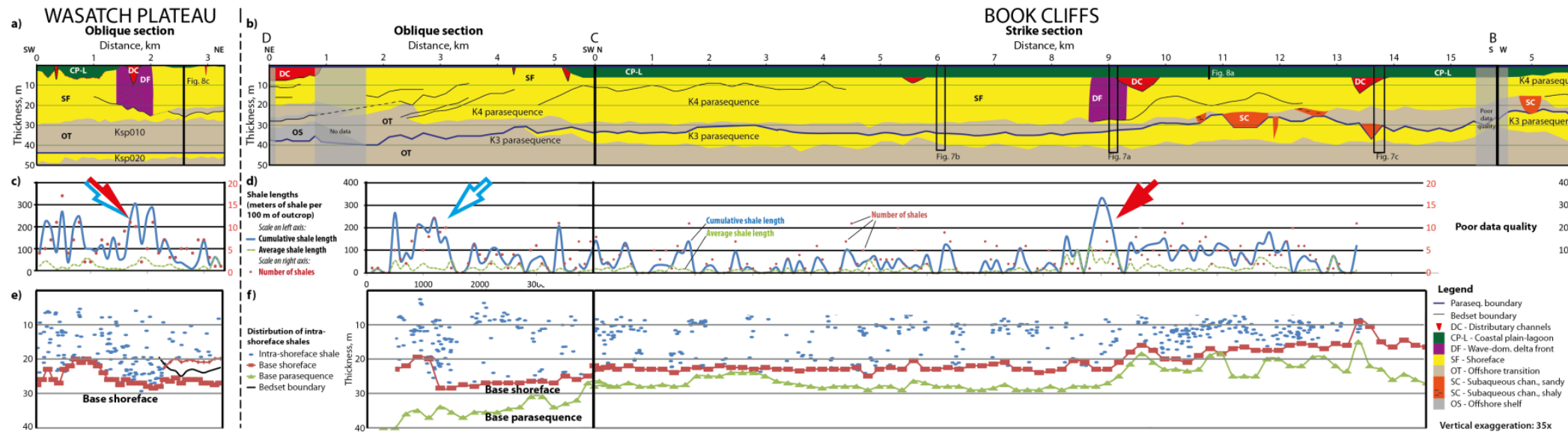

${ }_{\mathrm{s}} \mathrm{w}$

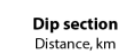

Dip section
Distance, km

Figure 10. Figure with plots of facies distribution for the outcrop of the Storrs KSP010 in the Wasatch Plateau (a) and Kenilworth 4 in the Book Cliffs (b). Cumulative length of intra-shoreface shales per $100 \mathrm{~m}$ of outcrop (blue lines), average length of intra-shoreface shales within $100 \mathrm{~m}$ sections of outcrop (green curve) and number of intrashoreface shales within each bin (red circles) is plotted for the KSP010 and K4 is plotted in c and d respectively. See Figure 6 for a schematic illustration for how this is calculated. Location of each shale in the studied dataset, depth to base of shoreface and to the top of the underlying parasequence is plotted in e and f for the KSP010 and K4, respectively. 
The thickness of the Ksp010 shoreface increases around the clinoform, from a thickness of 20 $\mathrm{m}$ at both $1 \mathrm{~km}$ and $2.5 \mathrm{~km}$ along the model to a thickness of $27 \mathrm{~m}$ at $1.9 \mathrm{~km}$ along the model.

Below the distributary channel, recessive breaks and bed boundaries in the shallow-marine sandbody are convex-upwards, with the apex of the recessive breaks below the center of the channel. These are interpreted to represent mouth-bars deposited by a wave-dominated delta. This zone is approximately $0.7 \mathrm{~km}$ wide.

\section{Facies in the Kenilworth K4 parasequence}

The scan of the Kenilworth $\mathrm{K} 4$ parasequence is divided into three sections (Figure 1, 10b). $\mathrm{AB}$ is approximately parallel to depositional dip, $\mathrm{BC}$ is approximately parallel to depositional strike, and $\mathrm{CD}$ is approximately $45^{\circ}$ oblique to depositional strike. The Kenilworth K3 parasequence crops out in the lowermost portion of the scan, and the Kenilworth K3 shoreface pinches out towards the east in sections $\mathrm{AB}$ and $\mathrm{CD}$ (Figure 10b). Along strike, in model BC, the thickness of the Kenilworth K3 shoreface varies from $14 \mathrm{~m}$ to $4 \mathrm{~m}$, which is mainly controlled by distance to the pinch-out of the shoreface. The Kenilworth K3 parasequence is overlain by offshore transition deposits belonging to Kenilworth K4 parasequence in most of the outcrop, except for the most distal part in profile $\mathrm{CD}$ where the boundary is overlain by offshore shales, and the SW part of the model in profiles $\mathrm{AB}$ and $\mathrm{BC}$, where several subaqueous channels are present at and just above the parasequence boundary.

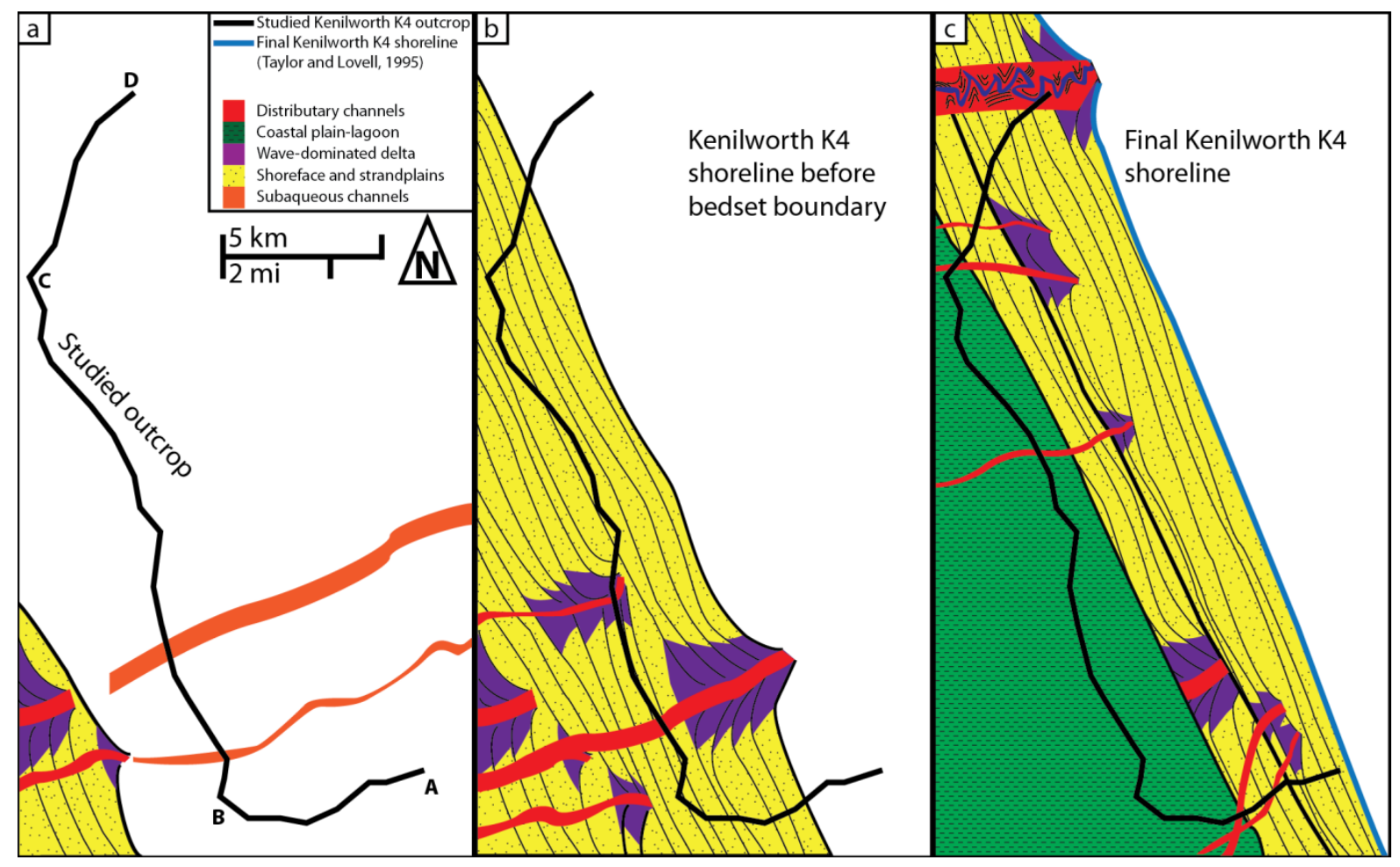

Figure 11. Paleogeographic maps showing possible arrangements of architectural elements explaining the observed distribution of architectural elements in the Kenilworth K4 parasequence (Figure 10b). All architectural elements shown to cross the studied profile are observed, and everything outside this profile is inferred. Orientation of channels is assumed to be sub-parallel to depositional dip, as channel orientations are not measured. (a) Prograding shoreline located to the west of the studied outcrop. Largest delta systems located 
near southeast corner of the outcrop, leading to subaqueous channels going through the study area. (b) Kenilworth K4 shoreline just before the bedset boundary. Note the small and rapidly avulsing delta systems. (c) Final shoreline of the Kenilworth K4 before transgression of the system.

A previously unrecognized $5.5 \mathrm{~m}$ thick lagoonal deposit (Figures 7a; 8a; 10b) is present on top of the Kenilworth $\mathrm{K} 4$ parasequence in the westernmost portions of section $\mathrm{AB}$ and $\mathrm{CD}$, and on top of the entire section BC. This deposit is overlain by a transgressive lag, and pinches out towards the east. The pinch-out of the lagoon is sub-parallel to the final shoreline of the Kenilworth K4 parasequence (Figure10).

The thickness of the Kenilworth K4 shoreface ranges from $15 \mathrm{~m}$ where the Kenilworth K3 parasequence is thickest, to $36 \mathrm{~m}$ seaward of the pinchout of the Kenilworth K3, where the Kenilworth K4 shoreline systems prograded into deeper water. The average shoreface thickness is $21 \mathrm{~m}$. Bedset boundaries and their updip manifestation as muddy clinoforms in the shoreface are abundant in the dip-sections $\mathrm{AB}$ and $\mathrm{CD}$, but are not as common in the along-strike section BC. Bedset boundaries, which occur at $1 \mathrm{~km}$ in section $\mathrm{AB}$ and $3 \mathrm{~km}$ in $\mathrm{CD}$, are associated with seaward-thinning tongues of shoreface overlain by offshore transition (blue outlined arrows in Figure 10c and 10d). Seaward of these tongues, the base of the contiguous shoreface is shifted up $6 \mathrm{~m}$. When these bedset boundaries are traced landwards, they intersect the seaward pinch-out of the lagoonal deposits, which also record a $5.5 \mathrm{~m}$ rise of the shoreface. These bedset boundaries in profile $A B$ and $C D$ occur parallel to the paleoshoreline of the Kenilworth $\mathrm{K} 4$ parasequence, indicating that they happened at the same time and were caused by the same event in profiles $\mathrm{AB}$ and $\mathrm{CD}$.

Eight channels incise into the top of the shoreface (Figures 10b, 11), and one of these channels overlies an interval of the shoreface with abundant, northward-dipping clinoforms (Figure 7a). This is interpreted to represent an asymmetric, wave-dominated delta. The other channels are interpreted to have fed deltas further paleoseaward. There is a general trend for the channels to become wider and more densely spaced towards the south in profile BC. Six subaqueous channels are present in the offshore transition in the Kenilworth K4 (Figure 10b, $\mathrm{BC})$, below where the distributary channels are widest and most abundant.

\section{$\underline{\text { Statistics and distribution of Intrashoreface shales }}$}

In order to characterize the variability of intrashoreface shales, the following four parameters were investigated: (1) The variation in amount of intrashoreface shales along the outcrop, (2) the variation in number of shales by depth in the shoreface, (3) the length distribution of intrashoreface shales, and (4) the length distribution of intrashoreface shales by depth in the shoreface.

\section{Amount of intrashoreface shale along outcrops}

The amount of intrashoreface shale is investigated primarily by using the cumulative shale length per $100 \mathrm{~m}$ of outcrop ("shale density"). Shale density per $100 \mathrm{~m}$ ranges from 0 to $332 \mathrm{~m}$, with an average value of $102 \mathrm{~m}$ and $59 \mathrm{~m}$ of shale per $100 \mathrm{~m}$ of outcrop for the Storrs Ksp010 and the Kenilworth K4 respectively. There is considerable variation along the 
outcrop, and the shale length per 100m of outcrop reaches more than $250 \mathrm{~m}$ in five locations. Two of these peaks are associated with the presence of wave-dominated deltas (filled red arrows in Figures 10a and 10b), while the rest occur at bedset boundaries caused by minor rises in relative sea-level (blue outlined arrows in Figures 10c and 10d). In the Storrs Ksp010 model, a wave-dominated delta and a minor sea-level rise occurs at the same location in the outcrop (Figure 10a).

A shale density of around $50 \mathrm{~m}$ per $100 \mathrm{~m}$ of outcrop is generally observed in shorefaces without bedset boundaries or wave-dominated deltas (see 2.5 to $3.3 \mathrm{~km}$ in Ksp010 in Figures $10 \mathrm{a}$ and 10c, and 0 to $8.5 \mathrm{~km}$ in profile BC in Kenilworth K4 in Figures 10b and 10d). Near bedset boundaries not associated with minor sea-level rises, the shale density is around $100 \mathrm{~m}$ of shale per $100 \mathrm{~m}$ of outcrop (see 9.5 to $13 \mathrm{~km}$ in BC in Figures 10b, 10d).

Average length of shale per $100 \mathrm{~m}$ (green curve in Figures 10c-d) and number of shales per $100 \mathrm{~m}$ of outcrop (red filled circles in Figures 10c-d) is also plotted. No solid trends are observed on the basis of these parameters, but there are indications that bedset boundaries are associated with larger amounts of shorter intrashoreface shales, while deltas are associated with an increase in the average length of intrashoreface shales.

The occurrence and prediction of these more shale-rich sections is discussed further below.

\section{Amount of intrashoreface shale by depth in shoreface}

The thickness of the shoreface varies significantly along the outcrop (Figures 10a, 10b), from a minimum of $15 \mathrm{~m}$ to a maximum of $36 \mathrm{~m}$, with an average of $21 \mathrm{~m}$. This must be corrected for to study how the amount of shale varies by depth in the shoreface. To do this, the thickness of the shoreface was normalized to 1 . The depth of each of the intrashoreface shales was modified accordingly by dividing the depth of the shale with the thickness of the shoreface, giving dimensionless depth in the shoreface, where 0 is the top of the shoreface and 1 is the base. This allows for shales in shorefaces of different thickness to be compared. The shales were divided into 13 bins based on dimensionless depth in the shoreface for each of the outcrop sections, and the amount of shales in each bin is plotted in Figure 12. The values are relatively scattered, but two main trends emerge: First, there is a marked decrease in abundance of shale upwards in the plots, as shown by the linear regression line (Figure 12). This trend is especially marked in the Storrs Ksp010 parasequence (Figure 12a). The second trend is an increase in the proportion of shale around the middle of the shoreface, which is prominent at normalized depths of 0.4 and 0.6 in the along-strike and oblique sections of the Kenilworth K4 parasequence respectively (stippled lines in Figures 12c and d). Possible interpretations for this are discussed later in the text. 


\section{Amount of intra-shoreface shales by depth in shoreface}

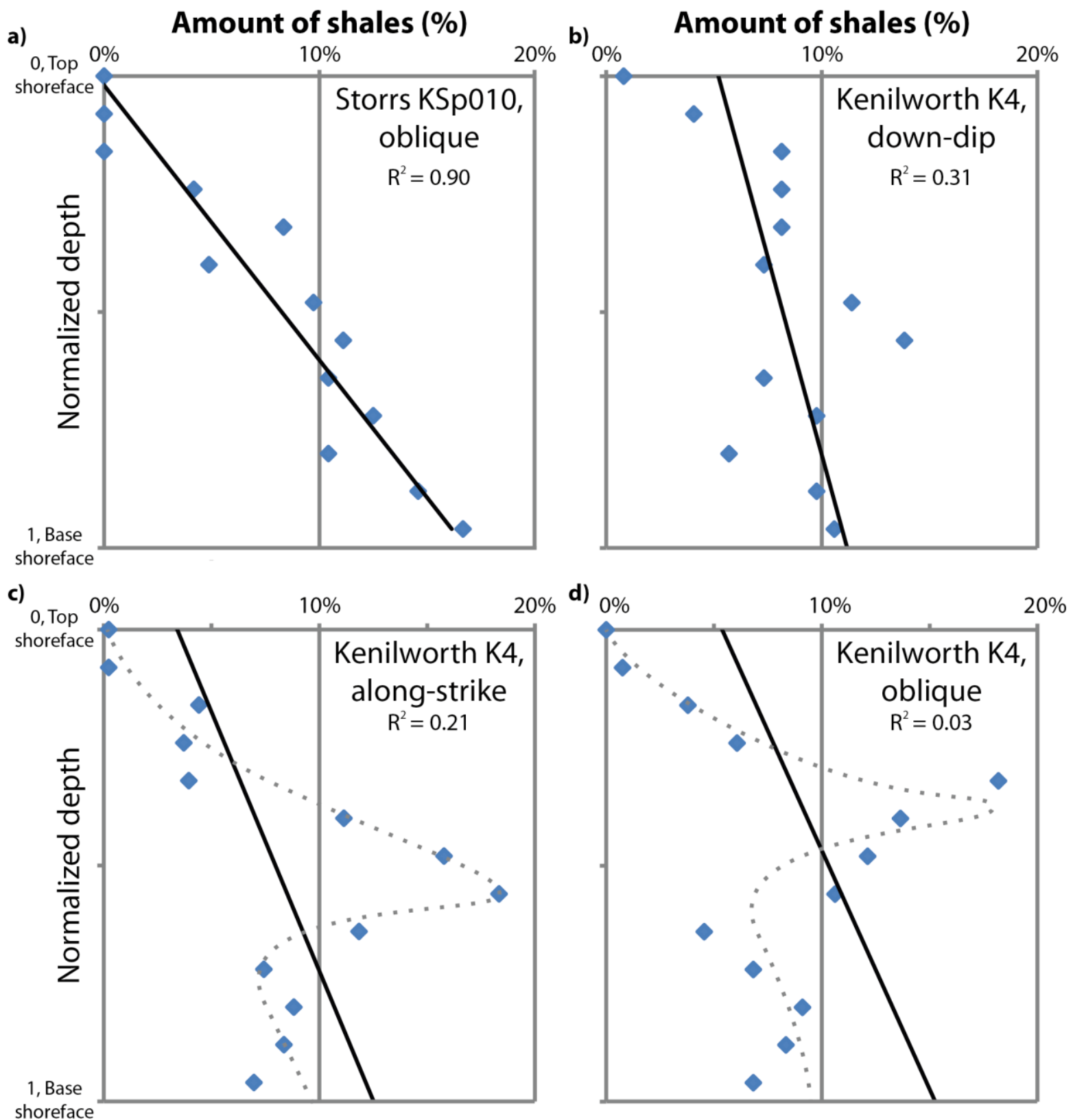

Figure 12. Plots of proportion of shale versus depth in the shoreface for the different studied outcrops. The depth values are normalized, as the thickness of the shoreface varies along the outcrop. 0 is thus the top of the outcrop and 1 is the base. Plots are shown for a) an oblique section through the Storrs KSp010 parasequence (Figure 10a), b) dip-oriented, c) strike-oriented, and d) oblique sections through the Kenilworth K4 parasequence (sections $\mathrm{AB}, \mathrm{BC}$ and $\mathrm{CD}$, respectively, in Fig 10b). Straight black lines are linear regression lines, stippled lines in (c) and (d) are hand-drawn best-fit curves.

\section{Length distribution of intrashoreface shales}

The distributions of shale lengths and statistical parameters for length populations in each of the outcrop sections are plotted in Figure 13. The shapes of the histograms indicate a 
lognormal distribution for the shale lengths, which is confirmed at a confidence level of $90 \%$ by using the Cramér von Mises-test for normality (Darling, 1957) on log-transformed values of the populations. The along-strike and down-dip populations of the Kenilworth K4 parasequence are shown to be statistically different using the Snedecor F-test for variances and the Student T-test for means (e.g. Davis, 2002), confidence levels of $98 \%$ and $99 \%$ respectively, suggesting the shales are elliptical, with long axes oriented perpendicular to the shoreline. The mean length of shales in the Kenilworth K4 parasequence down-dip and along-strike sections is $21.9 \mathrm{~m}$ and $13.8 \mathrm{~m}$ respectively. The mean length of the oblique section of the Kenilworth K4 parasequence is mid-way between those two values at $16.2 \mathrm{~m}$, which is to be expected if the shales are ellipses oriented normal to the paleoshoreline. The average length of the shales in the oblique section of the Storrs Ksp010 is 11.9 m, suggesting slightly smaller shales in this outcrop.

\section{Intra-shoreface shale length distributions}
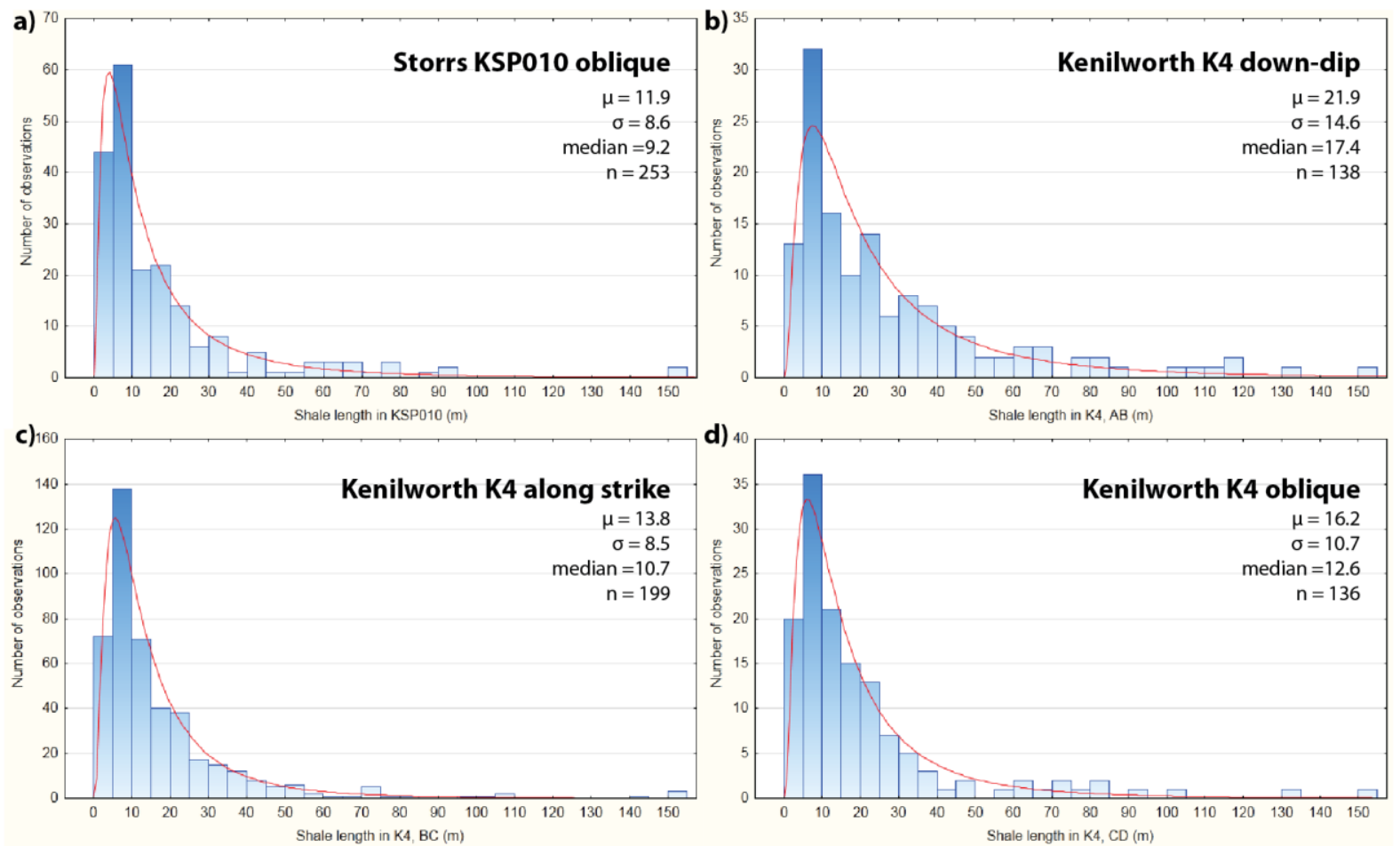

Figure 13. Histograms of shale lengths and widths with log-normal probability density functions (red curves) for shale populations in different outcrop sections. Plots are shown for a) an oblique section through the Storrs KSp010 parasequence (Fig. 9a), b) dip-oriented, c) strike-oriented, and d) oblique sections through the Kenilworth $\mathrm{K} 4$ parasequence (sections $\mathrm{AB}, \mathrm{BC}$ and $\mathrm{CD}$, respectively, in Fig 9B). $\mu$, mean; $\sigma$, standard deviation. 
Length variations by depth in shoreface

Tests were also performed to investigate whether shale size (length and width taken as one) is dependent on depth in the shoreface. A simple plot of the logarithm of shale lengths against depth (Figure 14) shows no relationship between depth and shale length.

\section{Discussion}

The aims of the study were to use the empirical observations of facies architecture to improve understanding of the distribution of intrashoreface shales within the two studied intervals from eastern Utah. This is addressed by considering the controls on the sedimentary architecture and the observed

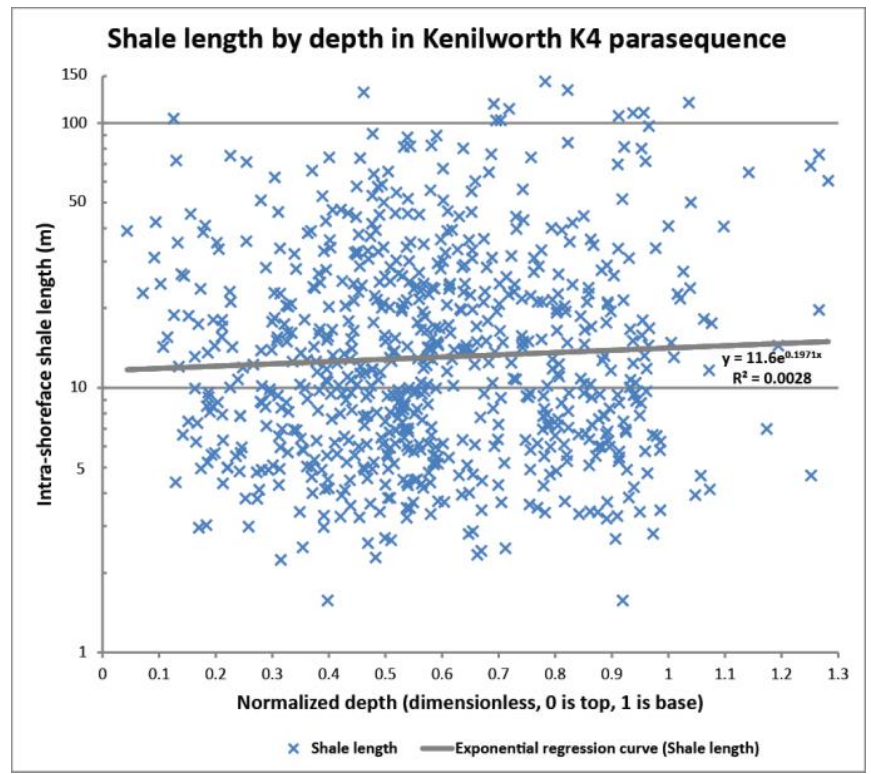

Figure 14. Plot of shale length versus depth in shoreface from the down-dip section of the Kenilworth K4 parasequence (section $\mathrm{AB}$ in Fig. 9b). The grey line is an exponential regression line for all the shale lengths. The plot shows that depth in the shoreface does not control the length of intra-shoreface shales to a significant degree. See text for further discussion. distribution of associated shales.

Finally a predictive model is proposed which has application for analogous systems.

\section{Controls on sedimentary architecture}

The lagoonal deposits in the eastern part of the Kenilworth K4 parasequence (Figure 10b) are interpreted to form because of a punctuated, regional $5.5 \mathrm{~m}$ rise in relative sea-level. There are four pieces of evidence for this: (1) the seaward-pinchout of the $5.5 \mathrm{~m}$ thick overlying lagoonal deposits (Figure 10b); (2) the pinch-out of lagoonal deposits occurs parallel to the paleoshoreline (Figure 11); (3) the presence of aggradationally-stacked bedsets seawards of the pinch-out of lagoonal deposits, which lead to a $5.5 \mathrm{~m}$ rise in the boundary between shoreface and offshore transition (Figure 10b); and (4) the thickening of shoreface deposits around the bedset boundaries associated with relative sea-level rise, and subsequent thinning of the shoreface paleoseaward of the bedset boundary $(0.5 \mathrm{~km}$ in $\mathrm{AB}$ in Figure $10 \mathrm{~b}, 2 \mathrm{~km}$ in $\mathrm{CD}$ in Figure 10b). Similar relationships are observed in the scanned exposure of the Storrs Ksp010 (Figure 10a), where the boundary between shoreface and coastal plain steps up in the same amount as the boundary between offshore transition and shoreface, and the shoreface thickens around the clinoform in the same amount as the interpreted sea-level rise. In neither case is the interpreted sea-level rise associated with a landward dislocation of the shoreline. 
a)

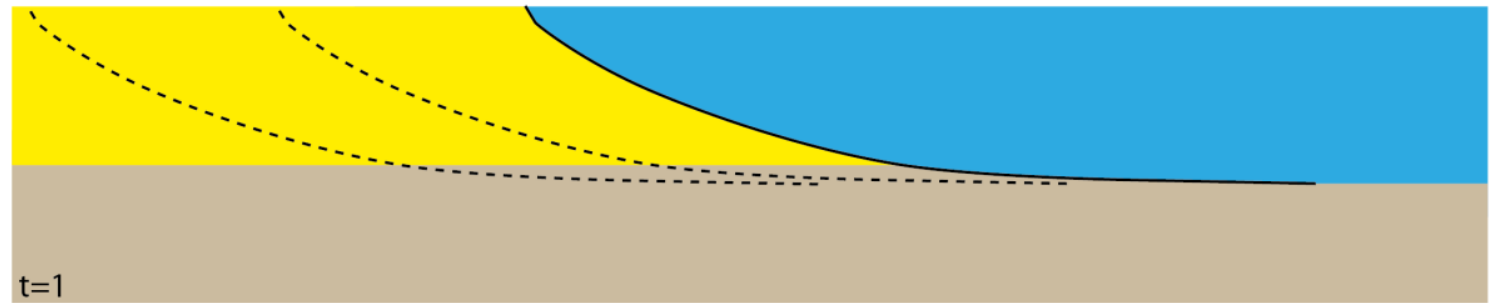

b)

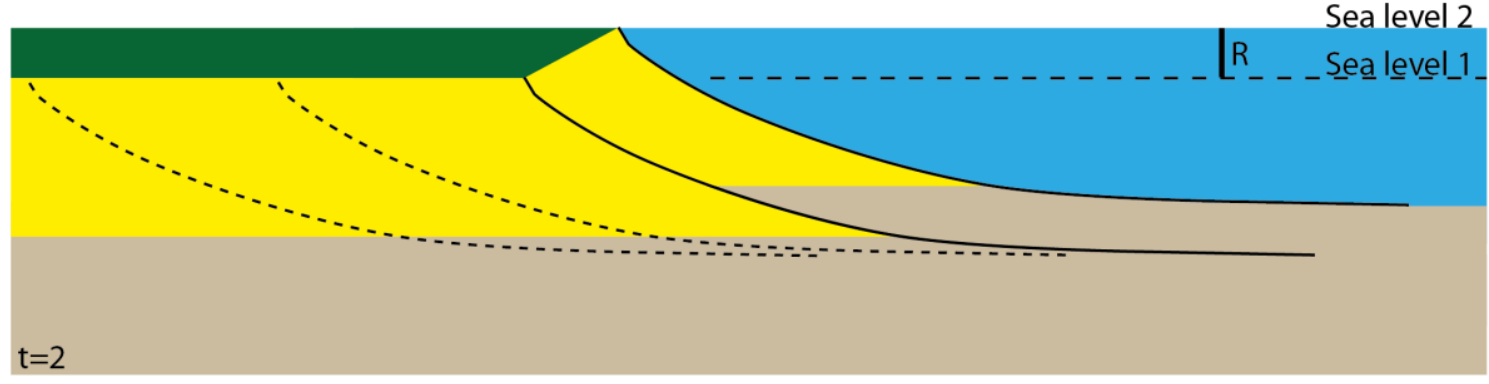

$\log 1$

$\log 3$

c)

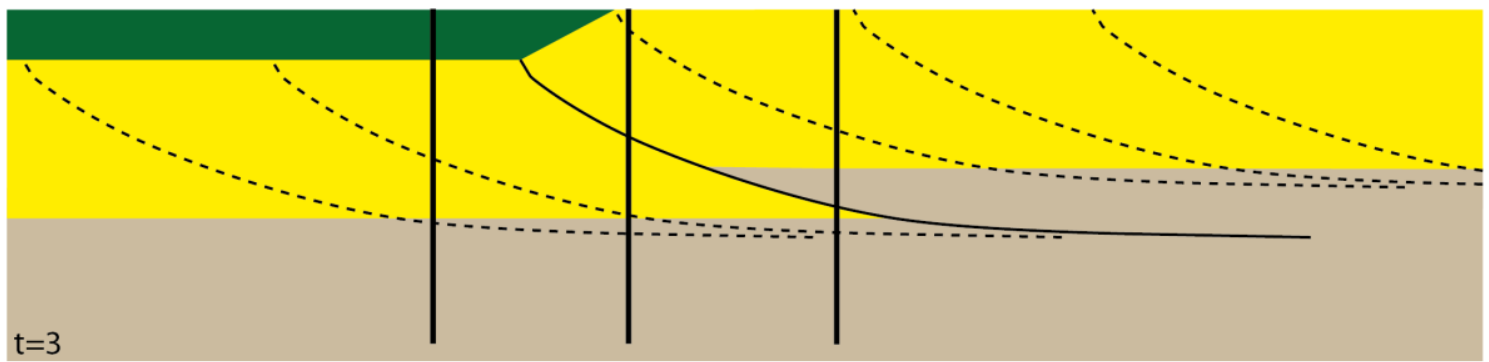

d)

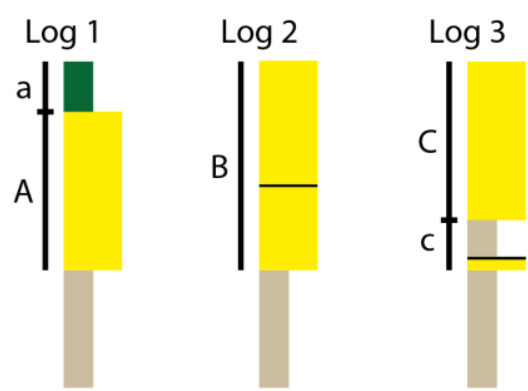

$A+a \approx B \approx C+C$ $\mathrm{a} \approx \mathrm{C} \approx \mathrm{R}$

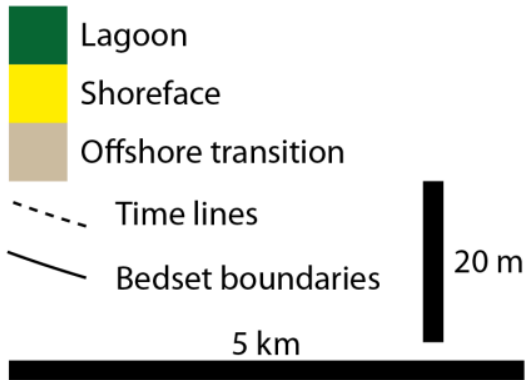

Vertical exaggeration: $75 \mathrm{x}$

Figure 15. Possible conceptual model for the development of the outcrop of the Storrs KSP010 shoreline in this study. The Kenilworth 4 has the same history, but is followed by a major sea level rise and drowning of the shoreline system. (a) Flat normal regression under a relatively stable sea level leads to a flat shoreline trajectory. (b) A six meter relative sea-level rise occurs. The sediment supply is larger than the rate of accommodation creation, and there is consequently no landward displacement of the shoreline. The relative sea level rise leads to a steep normal regression, the development of a bedset, infilling of coastal plain behind the shoreline and a stranded tongue of lower shoreface. (c) The relative sea level rise ends, and the shoreline continues to prograde with a flat shoreline trajectory.

When a wave-dominated coastline progrades under a stable sea-level, the thickness of the shoreface sandbody is primarily controlled by depth to average wave-base (e.g. Howell and Flint, 2003; Figure 15a). When a minor (e.g. $5 \mathrm{~m}$ ) sea-level rise occurs, the shoreline 
trajectory (Helland-Hansen and Martinsen, 1996) is controlled by the ratio of sediment supply to accommodation creation. If the rate of accommodation creation outpaces sediment supply, the coastline will transgress, and a parasequence boundary will develop (Van Wagoner et al., 1990). Because the gradient of the coastal plain is very small (less than $0.1^{\circ}$ ), a small sea-level rise can lead to rapid flooding of a large area (Kamola and Van Wagoner, 1995). Conversely, if the rate of sediment supply is greater than the rate of accommodation creation, no landward dislocation of the shoreline will occur, but the shoreline will prograde at a steeper angle and an aggradational stacking of bedsets (sensu Van Wagoner, 1990) will occur in front of the shoreline (Figure 15b). Further progradation under a stable sea-level will lead to a return to a flat shoreline trajectory (Figure 15c). Such a sea-level history will lead to specific geometric arrangements of the resulting deposits: An exposure immediately paleolandward of the shoreline at the time of relative sea-level rise will be overlain by coastal plain deposits with a thickness equal to the sea-level rise (log 1 in Figure 15d), while an exposure immediately basinward of the shoreline at the time of the sea-level rise will record a change in facies resulting from the sea-level rise (log 3 in Figure 15d). The area near the shoreline at the time of sea-level rise will display a thickening of the shoreface equal to the sea-level rise, because of the steeper trajectory ( $\log 2$ in Figure 15d). This relationship is similar to that observed in the investigated outcrops (Figures 10a, 10b).

Charvin et al. (2011) used inverse modelling to demonstrate how variations in relative sealevel changes, sediment supply and wave-regime influences stratigraphic architecture in wave-dominated shallow-marine deposits at intra-parasequence scale in the Aberdeen A0 and A1 parasequences of the Blackhawk Formation (Figure 2). The results showed that the gross architecture is controlled by relative sea-level and sediment supply, while variations in wave climate controlled localized variations in sandbody thickness. Accommodation created landward of the shoreline was filled by lagoonal or coastal plain deposits, and the shape of the boundary between shoreface sandstones and continental deposits clearly mirrored both rises and falls in relative sea-level. It is possible that part of the thickening of the shoreface in the Kenilworth $\mathrm{K} 4$ parasequence from $4 \mathrm{~km}$ to $2 \mathrm{~km}$ (AB in Figure 10b) is due to increased wave-energy when the coastline prograded into the deeper water seaward of the pinchout of the underlying Kenilworth K3 parasequence.

No obvious falls in sea-level are apparent from any of the scanned outcrops in this study (Figures 9a, 9b). In the Kenilworth K4 parasequence, a sharp-based (Plint, 1988; Taylor and Lovell, 1995) interval in the shoreface is recognized at $2.7 \mathrm{~km}$ in profile AB in Figure $15 \mathrm{~b}$, where it truncates a bedset boundary. This has been interpreted to represent a fall in relative sea-level by several authors (Pattison, 1995; Hampson and Storms, 2003). Judging from the topography on the top of the shoreface, such a fall must have been small in relation to the interpreted $5.5 \mathrm{~m}$ relative sea-level rise.

The entire Kenilworth $\mathrm{K} 4$ parasequence is regressive, with a net shoreline trajectory rise of $0.05^{\circ}$ using vertical and horizontal shoreline migration components of $13 \mathrm{~km}$ of progradation and $11 \mathrm{~m}$ of aggradation from Hampson (2010; figure 14). The entire Ksp010 has a shoreline trajectory rise of $0.02^{\circ}$, with a progradational distance of $45 \mathrm{~km}$ and a vertical component of $15 \mathrm{~m}$ (Hampson et al., 2011). The models in this study show an almost horizontal shoreline 
trajectory for most of the progradation recorded in the outcrop, interrupted by shortwavelength rises. The magnitude of the $5.5 \mathrm{~m}$ intra-parasequence sea-level rises observed in this study makes up for half of the aggradation of the entire Kenilworth K4 parasequence, and a third of the aggradation of the Storrs Ksp010. This suggests that accommodation was not generated by continuous, gentle subsidence, but rather abrupt, stepped pulses of relative sealevel rise. Kamola and Huntoon (1995) suggested that movements in thrust-sheets in the Sevier Orogen controlled the development of flooding surfaces and member boundaries in the Cretaceous foreland basin. It is also possible that such punctuated pulses of relative sea-level rise are caused by minor eustatic sea-level rises, or (climatically driven?) lows in sediment supply combined with gradual subsidence. It is not possible to differentiate between these models using the data presented in this work. It is possible that such pulses can occur at a range of scales, from the large, "member bounding" flooding-surfaces on top of the Spring Canyon SC7, Aberdeen A4, Kenilworth K4 and Grassy G4 parasequences (Figure 2; Hampson, 2010), to the c. $5 \mathrm{~m}$ rises observed as bedset boundaries in this study, and parasequence boundaries on top of e.g. the Storrs Ksp020, Spring Canyon SC5 and SC6 (Hampson, 2010; Hampson et al., 2011). Depending on the local sediment supply along the shoreline for an individual prograding system, it is possible that some of the smaller parasequences are developed as bedset boundaries outside the outcrop belt, and vice versa. Figure 10 shows that bedset-bounding clinoforms associated with relative sea-level rises occur together with threefold increase in the density of intrashoreface shales (Figure 16).

\section{Fluvial input points}

The plots of depositional elements along the scanned outcrops (Figures 10a, 10b) suggest that the shoreline of the Kenilworth K4 and Storrs Ksp010 parasequences consisted of wide (at least $9 \mathrm{~km}$ along strike) strandplains supplied by longshore drift, interrupted by relatively small wave-dominated deltas (about $1 \mathrm{~km}$ along strike) characterized by dipping, heterolithic clinoforms associated with channelized incisions. Other channelized incisions on top of shoreface deposits without evidence for fluvial influence are interpreted to have fed younger wave-dominated deltas further seaward (Figure 16a). Similar relationships are observed in satellite images of recent prograding shoreline systems (e.g. Vakarelov and Ainsworth, 2013). Eight channels are observed in the top of the Kenilworth K4 parasequence, but only one delta is present in the along-strike cross section BC (Figures 10b, 11), suggesting the individual deltas were only active for a limited amount of time (Figure 11).

The deltaic elements are characterized by dipping, oblique clinoforms with apparent dips of up to $2^{\circ}$ in along-strike sections when corrected for tectonic dip. The clinoform dips in the interpreted deltaic Panther Tongue of the Star Point Sandstone have dips between $0.4^{\circ}$ to $2.65^{\circ}$ (Enge et al., 2010). The similarity of the clinoform dips indicates that the outcrop of the delta in the Kenilworth $\mathrm{K} 4$ parasequence is viewed in a down-dip cut. Deltas in wavedominated settings are often deflected towards the direction of longshore drift (Wright, 1977; Dominguez, 1996; Bhattacharya and Giosan, 2003; Charvin et al., 2010), and previous workers have determined the longshore drift direction in the Book Cliffs to be towards the south (Taylor and Lovell, 1995; Slingerland and Keen, 1999; Charvin et al., 2010). However, the delta observed in the NNE-SSW-trending shoreline of the Kenilworth K4 parasequence 
contains clinoforms that dip locally towards the north (Figures 7a, 10b), indicating deflection opposite to regional longshore drift. This is contrary to what is commonly observed in the Star Point Sandstone and Blackhawk Formation (Charvin et al., 2010; Hampson et al., 2011), and it is possible that the relatively small delta in the Kenilworth K4 was deflected by a beach ridge, not by longshore drift.

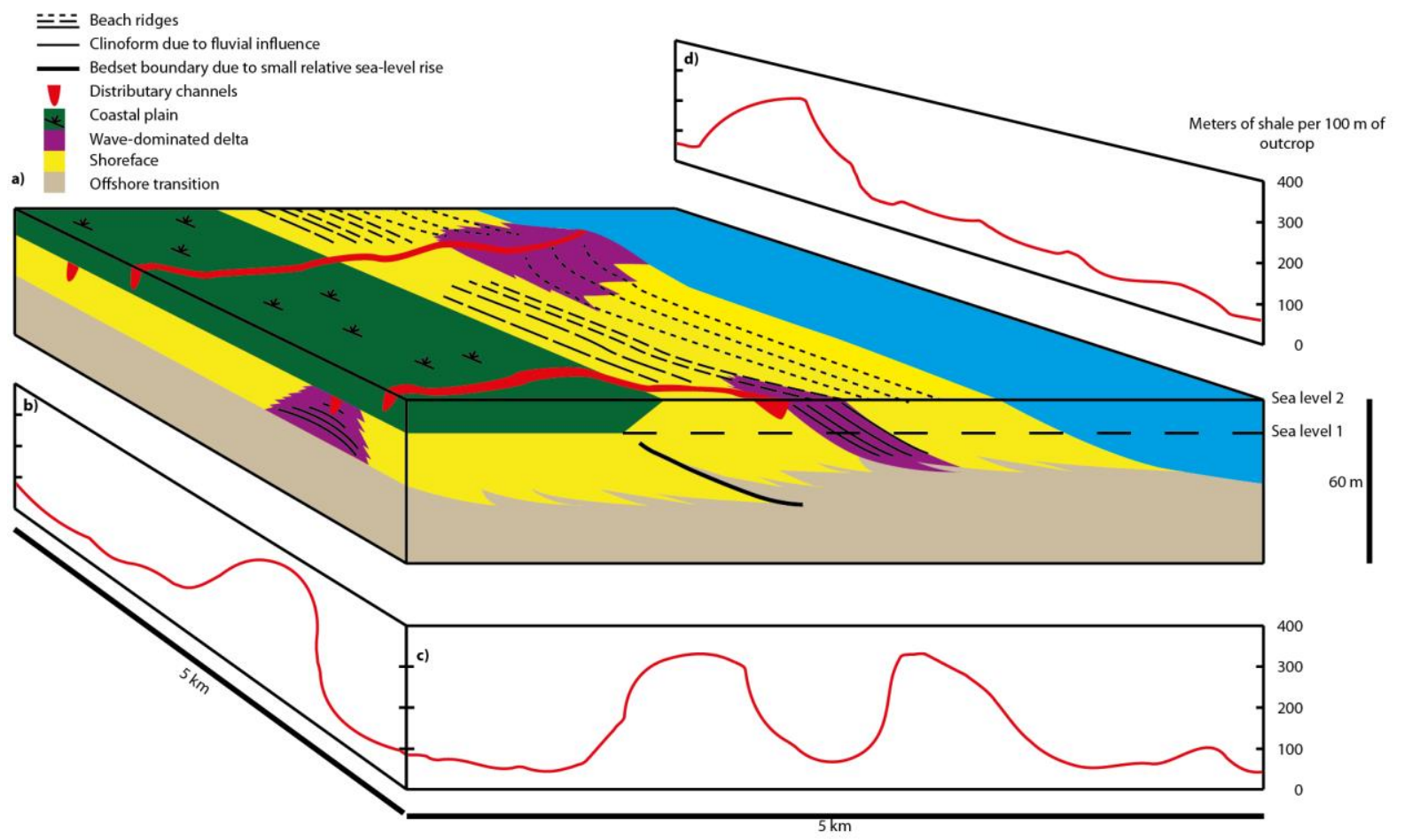

Figure 16. Shale density in wave-dominated shoreline systems as a function of stratigraphic architecture. (a) Block diagram showing simplified along-strike and down-dip profiles through, and a paleogeographic map of, a wave-dominated shoreline system similar to the one exposed in the Kenilworth 4 in the study area. The shoreline has locally-developed deltas separated by strandplains, and the location of the deltas change as the distributary channels avulse. The development of a coastal plain on the left side of the figure, the locally steep normal-regressive shoreline trajectory and the presence of the bedset boundary in the down-dip profile is caused by a punctuated minor rise in relative sea level. (b) Graph illustrating the length of intra-shoreface shale per 100 $m$ of outcrop in an along-strike section at an early stage of progradation in the study area. The intra-shoreface shale length is high near the deltaic interval around the lower distributary channel. (c) Graph illustrating the length of intra-shoreface shale per $100 \mathrm{~m}$ of outcrop in a down-dip section. Note the increased shale length around the bedset boundary and the wave-dominated delta. (d) Graph illustrating the length of intra-shoreface shale per $100 \mathrm{~m}$ of outcrop in an along-strike section at a late stage of progradation in the study area. Note the elevated shale length near the active delta.

Plots of horizontal shale density in the investigated outcrops show that deposits of wavedominated deltas contain approximately three times more shales than shoreface deposits (Figures 10c, 10d, 16). In wave-dominated systems, shorelines are primarily fed by longshore drift, interrupted by point-sourced fluvial input points (deltas). Rivers supply both sand and mud to the shoreline, while longshore drift winnows away mud-grade sediment and transports sand. Deposits of deltas are therefore more shale-rich and have poorer reservoir 
properties than the surrounding strandplain deposits (Bhattacharya and Giosan, 2003). Both the deltas observed in this study appear to prograde along the shoreline, and are therefore asymmetric wave-influenced deltas (Bhattacharya \& Giosan, 2003)

\section{Vertical shale abundance}

Plots of relative amounts of intrashoreface shales versus depth in the shoreface for the different faces of the outcrops are shown in Figure 12. The plots show two main trends: a downward increase in amount of shale (prominent in Figure 12a), and a peak around the middle of the shoreface (prominent in Figures 12c and 12d). The plots from the Kenilworth $\mathrm{K} 4$ parasequence show a very prominent peak in abundance in the middle of the shoreface, while the Storrs Ksp010 does not show such a peak. One possible explanation for this peak is that the Kenilworth K4 parasequence has a barred shoreline, where shales are deposited in lee of bars. This would imply a middle shoreface facies (e.g. Howell and Flint, 2003), but a highly bioturbated zone in the middle of the shoreface is not observed in the measured sections. The positions of all observed intrashoreface shales in the outcrop are plotted in Figures $10 \mathrm{e}$ and $10 \mathrm{f}$.

In the Storrs Ksp010, the plot of the relative number of intrashoreface shales (Figure 12a) shows a linear increase with depth, with very few shales in the upper half. In the Kenilworth $\mathrm{K} 4$ parasequence, the down-dip profile $\mathrm{AB}$ (Figure 10b) also shows an increase in the abundance of shale with depth, though the number of shales in the upper part of the shoreface is elevated (Figure 12b). This is probably due to the fact that this profile is very close to the pinch-out of the Kenilworth K4 shoreface, which probably experienced a rapidly rising shoreline trajectory shortly before the transgression, leading to greater preservation of shales.

The other two sections from the Kenilworth $\mathrm{K} 4$, the along-strike $\mathrm{BC}$ and the oblique $\mathrm{CD}$, show prominent peaks in relative amount of intrashoreface shales around the middle of the outcrop. When the position of intrashoreface shales in the outcrop is investigated (Figure 10f) it becomes apparent that the shales are concentrated around bedset-scale clinoforms in the shoreface. In the along-strike panel of the Kenilworth K4 parasequence (BC in Figure 10b), the shales are concentrated around two bedset-bounding clinoforms: in the middle of the outcrop, 0-8 km; and near the base of the outcrop, at $9-12 \mathrm{~km}$. The clinoforms are intersected at one level in the along-strike cliff faces, while outcrops that are oblique or parallel to depositional dip intersect the clinoforms at all levels (Figure 17). This gives down-dip sections increasing shale content with depth, while the placement of the shales is more dependent on the depth of the clinoform in along-strike sections. The gradual decrease in amount of shale upwards in the shoreface suggests that the amount of intrashoreface shale is not a direct function of the facies association (USF and LSF), but rather a function the decreasing chance of preservation as wave-energy increases upwards in the water column. 

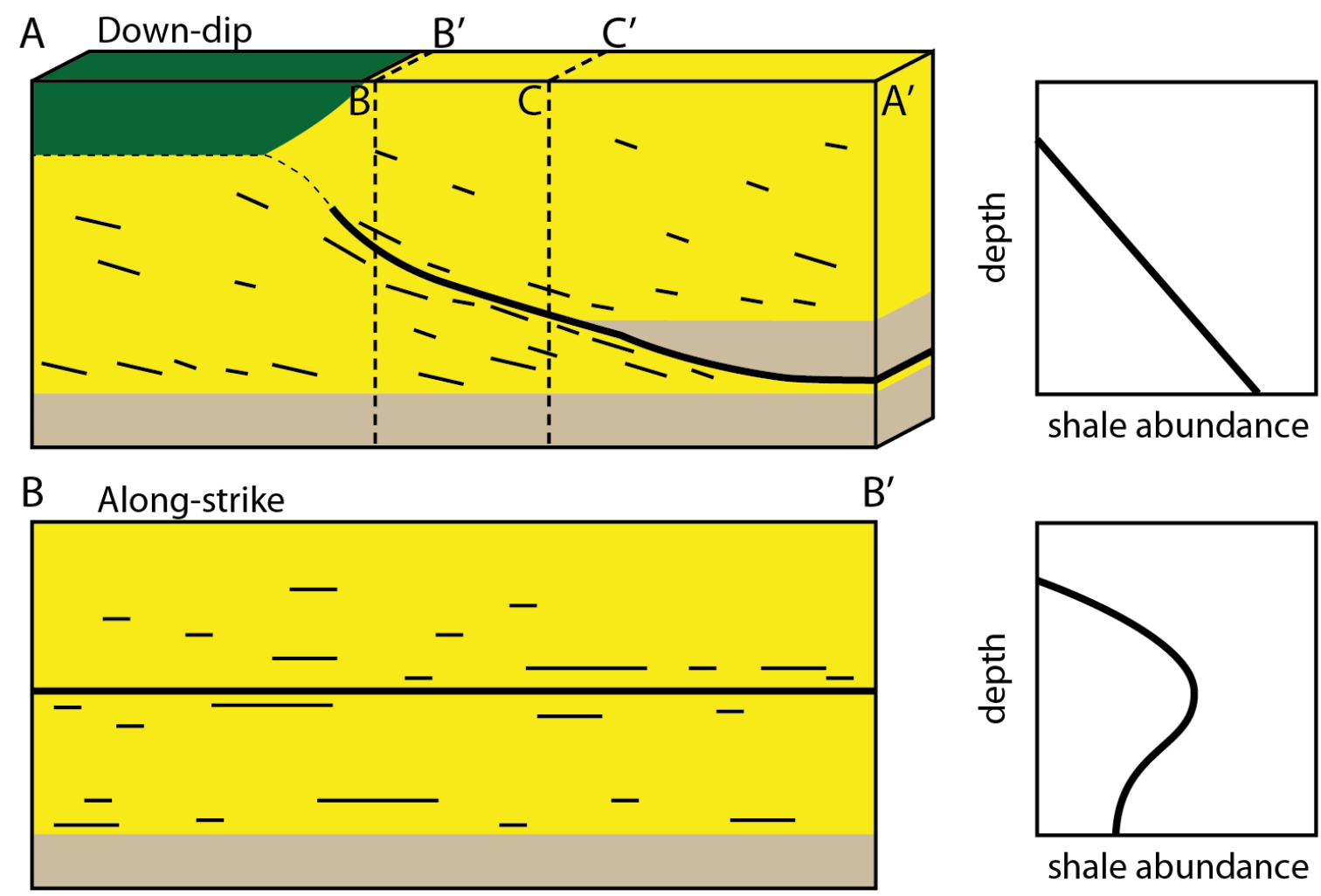

$\mathrm{B}^{\prime}$
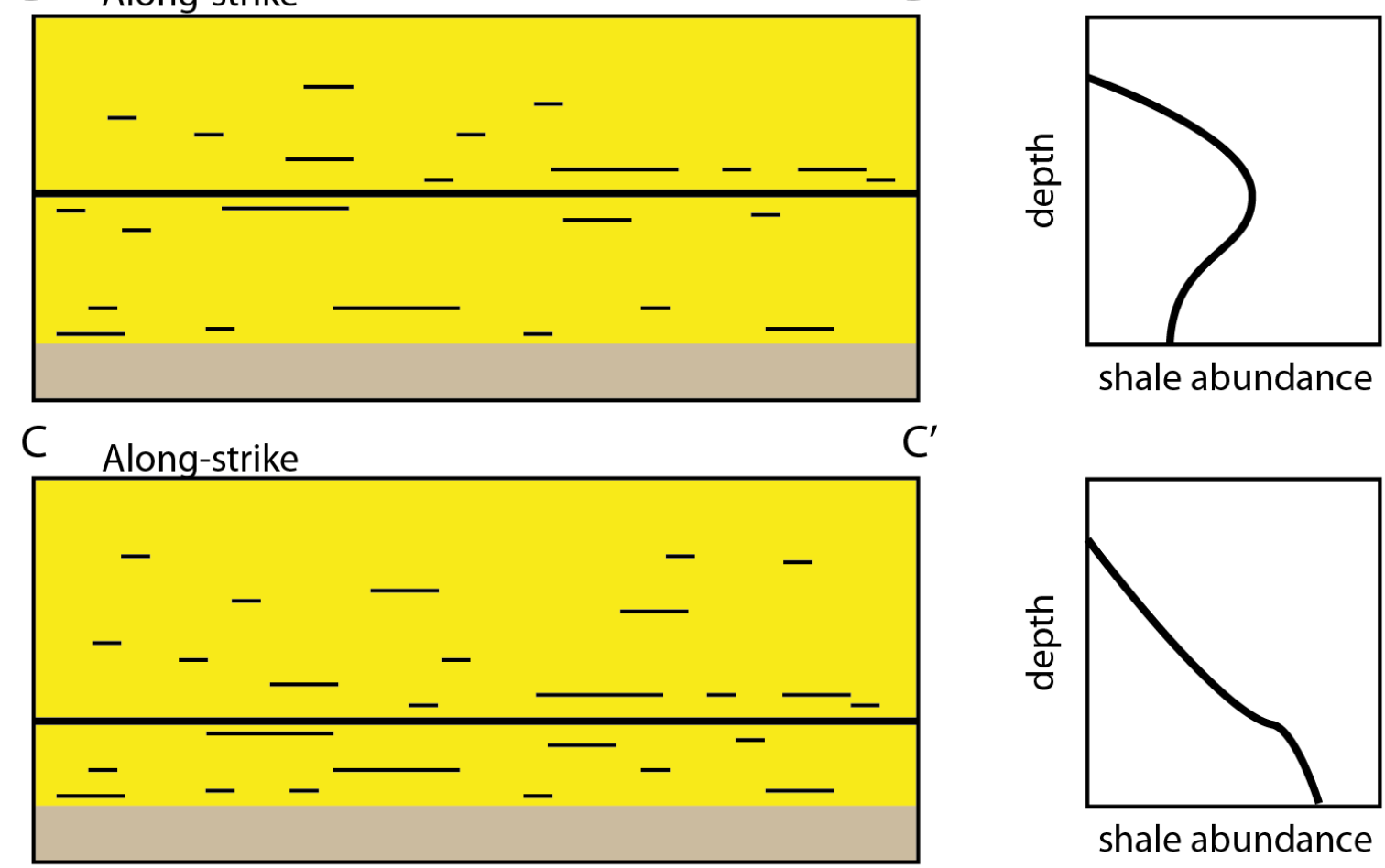

$C^{\prime}$

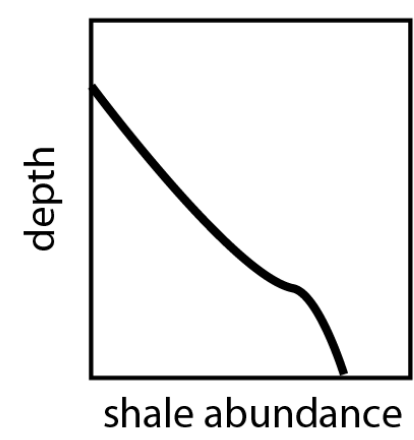

Figure 17. A possible explanation for the observed shale proportion:depth curves in Figure 12. Sketched proportion:depth curves indicate amount of shale versus depth in the facing side of the corresponding block diagram. (a) Plot of a down-dip section of a prograding shoreface. Shales are mostly concentrated around the bedset-bounding clinoform and in the base of the shoreface. Since the bedset-bounding clinoform goes through the profile, shales are sampled along its entire length, and the resulting shale proportion-graph shows an increasing abundance towards the base. (b) Plot of an along-strike profile intersecting the bedset-bounding clinoform in the middle of the outcrop. The shales are mainly concentrated along the bedset-bounding clinoform and the base of the shoreface, giving a shale proportion:depth plot with the majority of shales in the center of the outcrop. (c) Plot of an along-strike profile intersecting the bedset-bounding clinoform near the base of the outcrop, resulting in a concentration of shales at the base.

\section{Conclusion}

Heterogeneity in wave-dominated shallow-marine deposits has been investigated on both parasequence and bedset scale. In the present study, it is shown that the amount of intrashoreface shale is increased near bedset boundaries and near fluvial input points. 
Intrashoreface shale lengths are shown to have a log-normal distribution. The distribution of intrashoreface shales in the shoreface appears to be controlled by depth in the shoreface and the presence of bedset-bounding clinoforms. The amount of shales increases from near absence in the top of the shoreface, to abundant shales near the base of the shoreface. Shales are also clustered near bedset-scale clinoforms. The distribution of shales along the shoreface varies both in strike and dip. In the strike-direction, wave-dominated shorefaces have around $100 \mathrm{~m}$ of shale per $100 \mathrm{~m}$ of outcrop, but the amount of shale is commonly three times higher in deltaic areas near interpreted fluvial input points. In the down-dip-direction, the amount is also commonly increased by a factor of three in areas with bedset boundaries related to minor relative sea-level rises. This implies that reservoir properties in comparable hydrocarbon reservoirs will be worse in areas near fluvial input points and near minor rises in shoreline trajectory, two factors that can potentially be interpreted in high-quality seismic data.

\section{Acknowledgements}

Funding for this study was provided from the Research Council of Norway through the Petromaks project 193059 and the FORCE Safari Project. The lidar data was collected by Julien Vallet and Samuel Pitiot of Helimap Systems SA. Riegl LMS GmbH is acknowledged for software support. The first author would like to thank Oliver Severin Tynes for assistance in the field. Tore Grane Klausen and Gijs Allard Henstra are thanked for invaluable discussions. The authors would also like to thank Janok Bhattacharya, Cornel Olariu and one anonymous revier for their insightful comments which improved this paper, and Frances Witehurst for his editorial comments.

\section{References}

Arnot, M. J., 2001, Quantitative outcrop analogue data for modelling of storm-dominated, shallow marine shoreface reservoirs: PhD thesis, Heriot-Watt University, Edinburgh, Scotland, 337 p.

Ainsworth, R. B., 2005, Sequence stratigraphic-based analysis of reservoir connectivity: Influence of depositional architecture - a case study from a marginal marine depositional setting: Petroleum Geoscience, v. 11, p. 257-276.

Ainsworth, R. B., 2010, Prediction of Stratigraphic compartmentalization in marginal marine reservoirs: Geological Society, London, Special Publications, v. 347, p. 199-218.

Ainsworth, R. B., and S. A. J. Pattison, 1994, Where have all the lowstands gone? Evidence for attached lowstand systems tracts in the Western Interoir of North America: Geology, v. 22, p. 415-418.

Bellian, J. A., C. Kerans, and D. C. Jennette, 2005, Digital outcrop models: Applications of terrestrial scanning LIDAR technology in stratigraphic modeling: Journal of Sedimentary Research, v. 75, p. 166-176.

Bhattacharya, J. P., and L. Giosan, 2003, Wave-influenced deltas: Geomorphical implications for facies reconstruction: Sedimentology, v. 50, p. 187-210.

Bhattacharya, J. P. 2011, Practical problems in the application of the sequence stratigraphic method and key surfaces: integrating observations from ancient fluvial-deltaic wedges with Quaternary and modelling studies: Sedimentology, v. 58, p. 120-169.

Buckley, S. J., J. Vallet, A. Braathen, and W. Wheeler, 2008a, Oblique helicopter-based laser scanning for digital terrain modelling and visualisation of geological outcrops: Int Arch Photogrammetry, Remote Sens Spatial Inform Sci, v. 37, p. 493-498.

Buckley, S.J., J. A. Howell, H. D. Enge, and T. H. Kurz, 2008b, Terrestrial laser scanning in geology: data acquisition, processing and accuracy considerations: Journal of the Geological Society, v. 165 , p. 625-638. 
Buckley, S. J., H. D. Enge, C. Carlsson, , and J. A. Howell, 2010, Terrestrial Laser Scanning for use in Virtual Outcrop Geology: The Photogrammetric Record, v. 25, p. 225-239.

Burton, D., and L. J. Wood, 2011, Quantitative shale characterization of the tidally influenced Sego Sandstone: AAPG Bulletin, v. 93, p. 407-426.

Charvin, K., G. J. Hampson, K. L. Gallagher, J. E. A. Storms and R. Labourdette, 2011, Characterization of controls on high-resolution stratigraphic architecture in wave-dominated shoreface-shelf parasequences using inverse numerical modeling: Journal of Sedimentary Research, v. 81, p. 562-578.

Charvin, K., G. J. Hampson, K. L. Gallagher, and R. Labourdette, 2010, Intra-parasequence architecture of an interpreted asymmetrical wave-dominated delta: Sedimentology, v. 57, p. 760-785.

Clifton, H.E., 1976, Wave-formed sedimentary structures - a conceptual model, in R.A. Davis and R.L. Ethington, eds., Beach and Nearshore Sedimentation, SEPM Special Publication 24, p. 126-184.

Clifton, H. E., 2006, A re-examination of facies models for clastic shorelines, in H. W. Posamentier and R. G. Walker, eds., Facies models revisited: SEPM Special Publication 84, p. 293-337.

Colinson, J. D., N. P. Mountney, D. B. Thompson, 2006, Sedimentary structures: Harpenden, Terra Publishing, $296 \mathrm{p}$.

Darling, D. A., 1957, The Kolmogorov-Smirnov, Cramér-von Mises Tests: The Annals of Mathematical Statistics, v. 28, p. 823-838.

Davies, R. , C. Diessel, J. Howell, S. Flint, and R. Boyd, 2005, Vertical and lateral variations in the petrography of the Upper Cretaceous Sunnyside coal of eastern Utah, U.S.A.- Implications for the recognition of high-resolution accommodation changes in paralic coal seams: International Journal of Coal Geology, v. 61, p. 13-33.

Davies, R., J. Howell, R. Boyd, S. Flint and C. Diessel, 2006, High-resolution sequence-stratigraphic correlation between shallow-marine and terrestrial strata: Examples from the Sunnyside Member of the Cretaceous Blackhawk Formation, Book Cliffs, eastern Utah: AAPG Bulletin, v. 90, p 1121-1140.

Davis, J. C., 2002, Statistics and data analysis in geology: New York, Wiley, 656 p.

Dominguez, J. M. L., 1996, The São Francisco strandplain: a paradigm for wave-dominated deltas?: Geological Society, London, Special Publications, v. 177, p. 217-231

Dott, R. H., and J. Bourgeois, 1982, Hummocky stratification: Significance of its variable bedding sequences: Geological Society of America Bulletin, v. 93, p. 663-680.

Enge, H. D., S. J. Buckley, A. Rotevatn, and J. A. Howell, 2007, From outcrop to reservoir simulation model: Workflow and procedures: Geosphere, v. 3, p. 469-490.

Enge, H. D., J. A. Howell, and S. J. Buckley, 2010, Quantifying clinothem geometry in a forcedregressive river-dominated delta, Panther Tongue, Utah, USA: Sedimentology, v. 57, p. 17501770.

Elliott, T., 1978, Deltas, in H. G. Reading, ed., Sedimentary Environments and Facies 2, p. 113-154.

Flores, R. M., L. F. Blanchard, J. D. Sanchez, W. B. Marley, and W. J. Muldoon, 1984, Paleogeographic controls of coal accumulation, Cretaceous Blackhawk formation and Star Point Sandstone, Wasatch Plateau, Utah: Geological Society of America, Bulletin, v. 95, p. 540-550.

Fouch, T.D., T. F. Lawton, D. J. Nichols, W. B. Cashion, and W. A. Cobban, 1983, Patterns and timing of synorogenic sedimentation in Upper Cretaceous rocks of central and northeast Utah, in M.W. Reynolds and E.D. Dolly, eds., Mesozoic Paleogeography of the West-Central United States pp. 305-336.

Galloway, W. E., P.E. Ganey-Curry, X. Li, and R. T. Butler, 2000, Cenozoic depositional history of the Gulf of Mexico basin: AAPG Bulletin, v. 84, p. 1743-1774.

Haldorsen, H.H., Brand, P.J., Macdonald, C.J.,1987. Review of the stocastic nature of reservoirs: The Mathematics of Oil Production, p. 109-209.

Haldorsen, H. H., and L. W. Lake, 1984, A new approach to shale management in field-scale models: Society of Petroleum Engineers Journal, v. 24, p. 447-457.

Helland-Hansen, W., and O. J. Martinsen, 1996, Shoreline trajectories and sequences: description of variable depositional-dip scenarios: Journal of Sedimentary Research, v. 66, p. 670-688 
Hampson, G. J., 2010, Sediment dispersal and quantitative stratigraphic architecture across an ancient shelf: Sedimentology, v. 57, p. 96-141.

Hampson, G. J., M. Royhan Gani, K. E. Sharman, N. Irfan, and B Bracken, 2011, Along-strike and down-dip variations in shallow-marine sequence stratigraphic architecture: Upper Cretaceous Star Point Sandstone, Wasatch Plateau, Central Utah, U.S.A.: Journal of Sedimentary Research, v. 81, p. 159-184.

Hampson, G. J., M. Royhan Gani, H. Sahooo, A. Rittersbacher, N. Irfan, A. Ranson, T. O. Jewell, N. D. S. Gani, J. A. Howell, S. J. Buckley and B. Bracken, 2012, Controls on large-scale patterns of fluvial sandbody distribution in alluvial to coastal plain strata: Upper Cretaceous Blackhawk Formation, Wasatch Plateau, Central Utah, USA: Sedimentology, v. 59, p. 2226-2258.

Hampson G. J., and J. E. A. Storms, 2003, Geomorphical and sequence stratigraphic variability in wave-dominated, shoreface-shelf parasequences: Sedimentology, v. 50, 667-701

Hodgetts, D., and J. A. Howell, 2000, Syntheic seismic modeling og a large-scale geological crosssection from the Book Cliffs, Utah, USA: Petroleum Geoscience, v. 6, p. 221-229.

Hodgetts, D., J. Imber, C. Childs, S. Flint, J. Howell, J. Kavanagh, P. Nell and J. Walsh., 2001, Sequence stratigraphic responses to shoreline-perpendicular growth faulting in shallow marine reservoirs of the Champion Field, offshore Brunei Darussalam, South China Sea: AAPG Bulletin, v. 85, p. 433-457.

Howell, J. A., and S.S. Flint, 2003, Siliciclastics case study: the Book Cliffs, in A. Coe, ed., The Sedimentary Record of Sea-Level Change: Cambridge, U.K., Cambridge University Press, p. 135-208.

Howell, J. A., S. S. Flint, and C. Hunt, 1996, Sedimentological aspects of the Humber Group (Upper Jurassic) of the South Central Graben, UK North Sea: Sedimentology: v. 43, p. 89-114.

Howell, J. A., A. Skorstad, A. MacDonald, A. Fordham, S. Flint, B. Fjellvoll and T. Manzocchi, 2008a, Sedimentological parameterization of shallow-marine reservoirs: Petroleum Geoscience, v. 14, p. $17-34$.

Howell, J. A., A. Vassel and T. Aune, 2008b, Modelling of dipping clinoform barriers within deltaic outcrop analogues from the Cretaceous Western Interior Basin, USA, in: A. Robinson, P. Griffiths, S. Price, J. Hegre and A.H. Muggeridge, eds., The Future of Geological Modelling in Hydrocarbon Development. Geological Society of London Special Publications, p. 99-121.

Husmo, T., G. P. Hamar, O. Høiland, J. P. Johannessen, A. Rømuld, A. M. Spencer, and R. Titterton, 2003, Lower and Middle Jurassic, in D. Evans, C. Graham, A. Armour, and P. Bathurst, eds., The millenium atlas: Petroleum geology of the central and northern North Sea: London, Geological Society, p. 129-156.

Jackson, M. D., G. J. Hampson, and R. P. Sech, 2009, Three-dimensional modeling of a shorefaceshelf parasequence reservoir analog: Part 2. Geologic controls on fluid flow and hydrocarbon recovery: AAPG Bulletin, v. 93, p. 1183-1208.

Kadolsky, D., S. J. Johansen and S. Duxbury, 1999, Sequence stratigraphy and sedimentary history of the Humber Group (Late Jurassic-Ryazanian) in the Outer Moray Firth (UKCS, North Sea), in A. J. Fleet and S. A. R. Boldy, eds., Petroleum Geology of Northwest Europe: Proceedings of the $5^{\text {th }}$ conference, p. 839-860.

Kamola, D. L., and Huntoon, J. E., 1995, Repetitive stratal patterns in a foreland basin sandstone and their possible tectonic significance: Geology, v. 23, p. 177-180.

Kamola, D. L. and J. C. Van Wagoner, 1995, Stratigraphy and facies architecture of parasequences with examples from the Spring Canyon Member, Blackhawk Formation, Utah, J. C. Van Wagoner and G. T. Bertram, eds., Sequence Stratigraphy of Foreland Basin Deposits: Outcrop and Subsurface Examples from the Cretaceous of North America, AAPG Memoir 64, 27-54.

Kaufmann , E. G., and W. G. E. Caldwell, 1993, The Western Interior Basin in space and time, in W. G. E. Caldwell and E. G. Kauffman, eds., Evolution of the Western Interior Basin: Geological Association of Canada, Special Paper 39, p. 1-30.

Larue, D. K., and H. Legarre, 2004, Flow units, connectivity and reservoir characterization in a wavedominated delaic reservoir: Meren Reservoir, Nigeria: AAPG Bulletin, v. 88, p.303-324.

MacDonald, A. C., and J. O. Aasen, 1994, A prototype procedure for stochastic modeling of facies tract distribution in shoreface reservoirs, in J. M. Yarus and R. L. Chambers, eds., Stochastic modeling and geostatistics: AAPG Computer Applications in Geology 3, p. 91- 108. 
Martinius, A. W., P. S. Ringrose, C. Brostrøm, C. Elfenbein, A. Næss and J. E. Ringås, 2005, Reservoir challenges of heterolithic tidal sandstone reservoir in the Halten Terrace, midNorway: Petroleum Geoscience, v 11, p. 3-16.

Olariu, C., and J. P. Bhattacharya, 2006, Terminal distributary channels and delta front architecture of river-dominated delta systems, Journal of Sedimentary Research, v. 76, p. 212-233.

Pattison, S. A. J., 1995, Sequence stratigraphic significance of sharp-based lowstand shoreface deposits, Kenilworth Member, Book Cliffs, Utah: AAPG Bull., v. 79, p. 444-462.

Pattison, S. A. J., R. B. Ainsworth, and T. A. Hoffman, 2007, Evidence of across-shelf transport of fine-grained sediments: turbidite-filled shelf channels in the Campanian Aberdeen Member, Book Cliffs, Utah, USA: Sedimentology, v. 54, p. 1033-1063.

Plint, A. G., 1988, Sharp-based shoreface sequences and "offshore bars" in the Cardium Formation of Alberta: their relationship to relative changes in sea-level, in C. K. Wilgus, B. S. Hastings, C. G. St. C. Kendall, H. W. Posamentier, C. A. Ross, and J. C. Van Wagoner, eds., Sea-level changes: an integrated approach: SEPM Special Publication 42, p. 357-370.

Pringle, J. K., J. A. Howell, D. Hodgetts, A. R. Westerman, and D. M. Hodgson, 2006, Virtual outcrop models of petroleum reservoir analogs: A review of the current state-of-the-art: First Break, v. 24, p. 33-42.

Richards, P. C., and S. Brown, 1986, Shoreface storm deposits in the Rannoch Formation (Middle Jurassic), Northwest Hutton oil field: Scottish Journal of Geology, v. 22, p. 367-375.

Rittersbacher, A., S. J. Buckley, J. A. Howell, G. J. Hampson and J. Vallet, 2013, Helicopter-based laser scanning: a method for quantitative analysis of large-scale sedimentary architecture, in A. W. Martinius, J. A. Howell and T. Good, eds., Sediment-Body Geometry and Heterogeneity: Analogue Studies for Modelling the Subsurface. Geological Society, London, Special Publications, 387,

Sech, R. P., M. D. Jackson, and G. J. Hampson, 2009, Three-dimensional modeling of a shorefaceshelf parasequence reservoir analog: Part I: Surface-based modeling to capture high-resolution facies architecture: AAPG Bulletin, v. 93, p. 1155-1181.

Slingerland, R. L. and T. R. Keen, 1999, Sediment transport in the Western Interior Seaway of North America: Predictions of a climate-ocean-sediment model, in K. M. Bergman and J. W. Snedden, eds., Isolated Shallow Marine Sand Bodies: Sequence Stratigraphic Analysis and Sedimentologic Interpretation, SEPM Special Publication, 64, p. 179-190.

Stephen, K. D., C. Yang, J. N. Carter, J. A. Howell, T. Manzocchi and A. Skorstad, 2008, Upscaling uncertainty analysis in a shallow-marine environment: Petroleum Geoscience, v. 14, p. 71-84.

Storms, J. E. A., and G. J. Hampson, 2005, Mechanisms for forming discontinuity surfaces within shoreface-shelf parasequences: sea level, sediment supply or wave regime?: Journal of Sedimentary Research, v. 75, p. 67-81.

Sømme, T. O., J. A. Howell, G. J. Hampson, and J. E. A. Storms, 2008, Genesis architecture, and numerical modeling of intra-parasequence discontinuity surfaces in wave-dominated deltaic deposits: Upper Cretaceous Sunnyside Member, Blackhawk Formation, Book Cliffs, Utah, U.S.A., in G. J. Hampson, R. J. Steel, P. M. Burgess and R. W. Dalrymple, eds., Recent advances in models of siliciclastic shallow-marine stratigraphy: SEPM special publication 90 , p. 421-441.

Taylor, A. M., and R. Goldring, 1993, Description and analysis of bioturbation and ichnofabric: Geological Society of London, Journal, v. 150, p. 141-148.

Taylor, D. R., and R. W. W. Lovell, 1995, High-frequency sequence stratigraphy and paleogeography of the Kenilworth Member, Blackhawk Formation, Book Cliffs, Utah, USA., in J. C. Van Wagoner and G. T. Bertram, eds., Sequence Stratigraphy of Foreland Basin Deposits: Outcrop and Subsurface Examples from the Cretaceous of North America AAPG Memoir 64, p. 257275.

Taylor, K. G., R. L. Gawthorpe, C. D. Curtis, J. D. Marshall, and D. N. Awwiller, 2000, Carbonate cementation in a sequence-stratigraphic framework: Upper Cretaceous sandstones, Book Cliffs, Utah-Colorado: Journal of Sedimentary Research, v. 70, p. 360-372.

Vakarelov, B. K. and R. B. Ainsworth, In Press, A hierarchical approach to architectural classification in marginal marine systems - bridging the gap between sedimentology and sequence stratigraphy: AAPG Bulletin. 
Vallet, J. and J. Skaloud, 2004, Development and experiences with a fully-digital handheld mapping system operated from a helicopter: International Archives of the Photogrammetry, Remote Sensing and Spatial Information Sciences, 35, Part B5, 1-6.

Van Wagoner, J. C., R. M. Mitchum, K. M. Campion, and V. D: Rahmanian, 1990, Siliciclastic sequence stratigraphy in well logs, cores and outcrops: Concepts for high-resolution correlation of time and facies: AAPG Methods in Exploration Series 7, 55 p.

Young, R. G., 1955, Sedimentary facies and intertonguing in the Upper Cretaceous of the Book Cliffs, Utah-Colorado: Bulletin of the Geological Society of America, v. 66, p. 177-202.

Wellner, R., R. Beaubouef, J. Van Wagoner, H. Roberts, and T. Sun, 2005, Jet-plume depositional bodies - The primary building blocks of Wax Lake delta: Gulf Coast Association of Geological Societies Transactions, v. 55, p. 867-909.

White, C. D., and B. J. Willis, 2000, A Method to Estimate Length Distributions from Outcrop Data: Mathematical Geology, v. 32, p. 389-419.

Wright, L. D., 1977, Sediment transport and deposition at river mouths: a synthesis: Bulletin of the Geological Society of America, v. 88, p. 857-868.

Zeito, G. A., 1965, Interbedding of shale breaks and reservoir heterogeneities: Journal of Petroleum Technology, v. 17, no. 10, p. 1223-1228. 